\section{IMS}

Information

Management

School
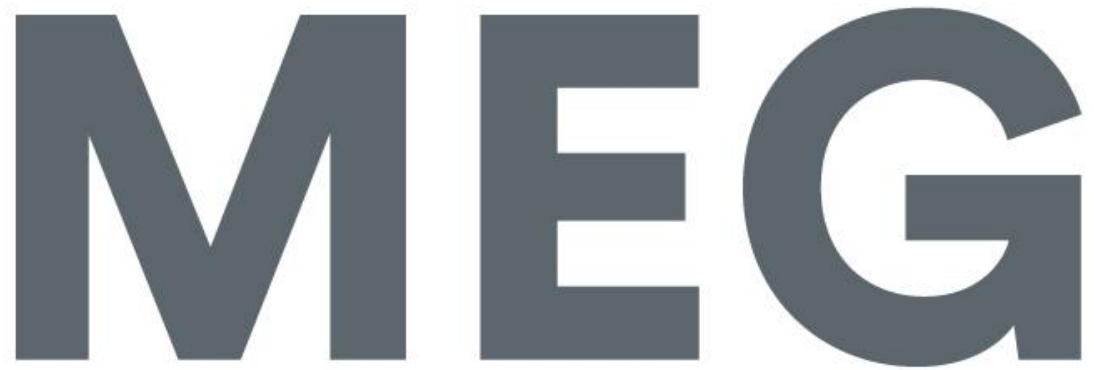

Mestrado em Estatística e Gestão de Informação Master Program in Statistics and Information Management

\section{Digital Divide at Individual Level: Evidence for Eastern and Western European Countries}

Petya Rangelova Chipeva

Dissertation presented as partial requirement for obtaining the Master's degree in Statistics and Information Management

NOVA Information Management School Instituto Superior de Estatística e Gestão de Informação 
Title: Digital Divide at Individual Level: Evidence for

Petya Rangelova Chipeva

Eastern and Western European Countries 

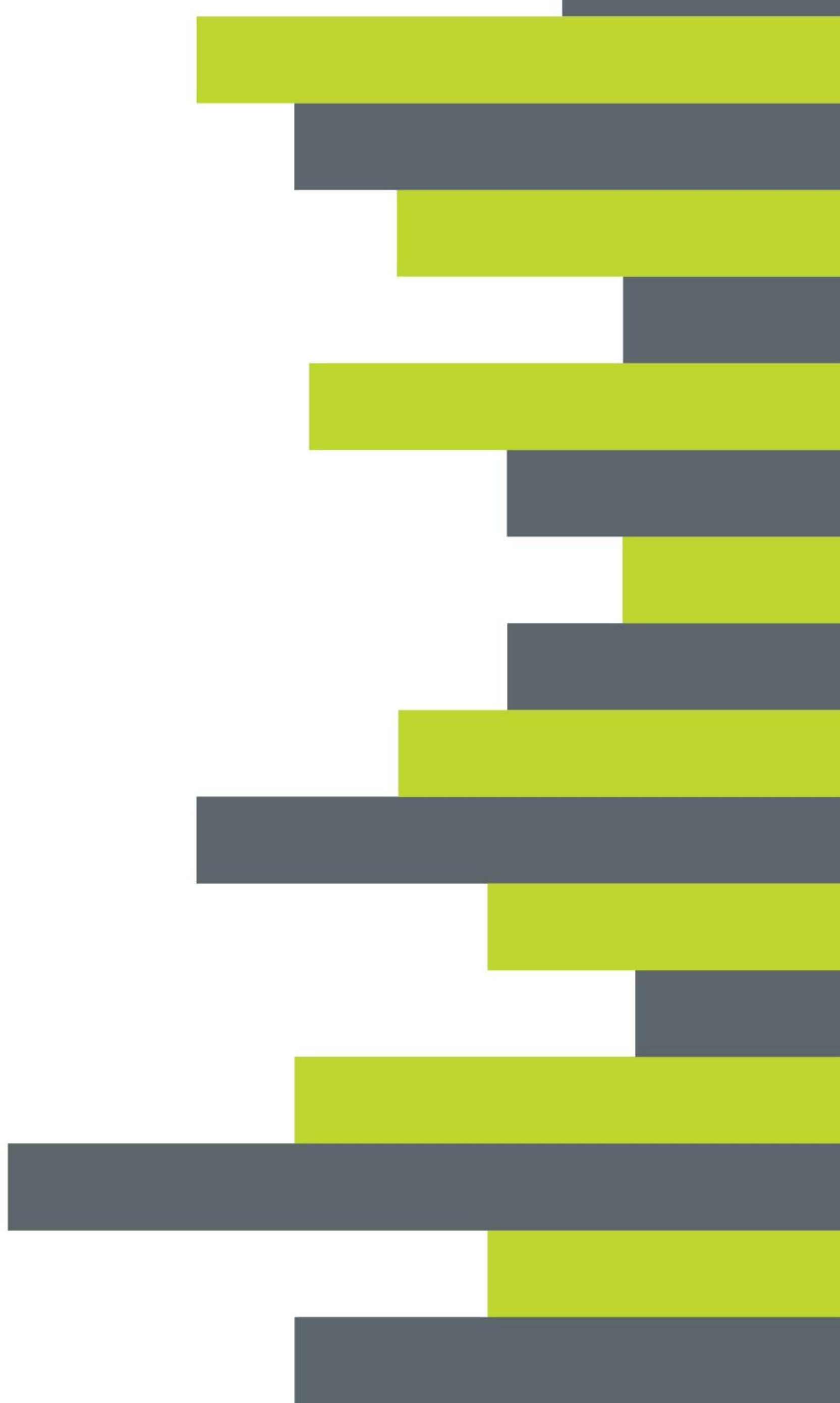


\author{
NOVA Information Management School \\ Instituto Superior de Estatística e Gestão de Informação \\ Universidade Nova de Lisboa
}

\title{
Digital Divide at Individual Level: Evidence for Eastern and Western European Countries
}

by

Petya Rangelova Chipeva

Dissertation presented as a partial requirement for obtaining the Master's degree in Statistics and Information Management, with a specialization in Information Analysis and Management

Co-Advisors: Tiago Oliveira

Frederico Cruz-Jesus 
November 2016

\section{ACKNOWLEDGEMENTS}

MY MOST SINCERE THANKS TO:

FIRST AND FOREMOST, MY THESIS CO-ADVISORS, TIAGO OLIVEIRA AND FREDERICO CRUZ-JESUS, FOR THEIR TIME, SUPPORT, MOTIVATION, DEDICATION, IDEAS AND KNOWLEDGE SHARED.

SECOND, MY FRIEND DESSIE, FOR THE ENCOURAGEMENT AND EDITING HELP.

FINALLY, ALL THE INDIVIDUALS WHO WILLINGLY PARTICIPATED IN THIS RESEARCH. 


\begin{abstract}
The current study explores the digital divide by checking the phenomenon at the individual level. It digs into the individual pattern of adoption and use of a broad set of information and communications technologies (ICTs) by introducing a conceptual model combining the extended unified theory of acceptance and use of technology (UTAUT2) and the five-factor model of personality. Therefore, it provides insights on factors affecting technology adoption and the role of personality on individual usage behavior. Most of the UTAUT2 hypotheses are supported, with performance expectancy being the strongest predictor. Openness is a significant predictor of behavioral intention, whereas for usage behavior the significant personality predictors are openness, extraversion and agreeableness. Moreover, as data was collected in Bulgaria and Portugal, a multigroup analysis revealed significant country differences. The effect of performance expectancy, habit, agreeableness and neuroticism on behavioral intention, as well as the effect of age on usage, are stronger for Bulgaria, whereas the effect of hedonic motivation on behavioral intention and the effect of behavioral intention on usage are stronger for Portugal.
\end{abstract}

\title{
KEYWORDS
}

Information and communications technologies (ICTs); digital divide, extended unified theory of acceptance and use of technology (UTAUT2); personality 


\section{INDEX}

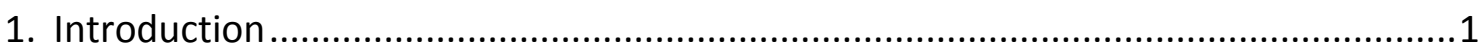

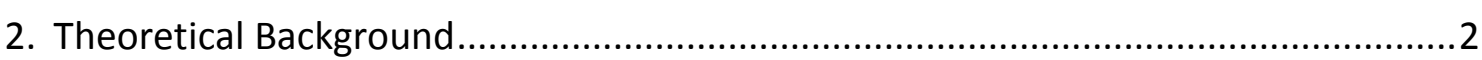

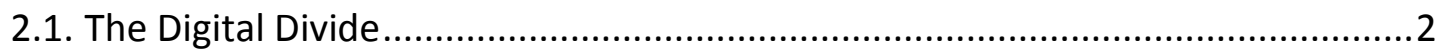

2.2. Adoption models at the individual level .........................................................4

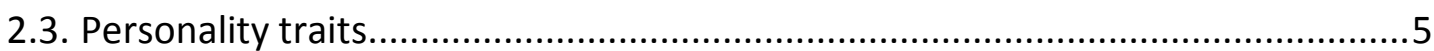

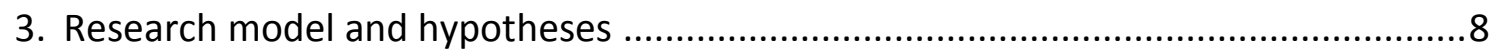

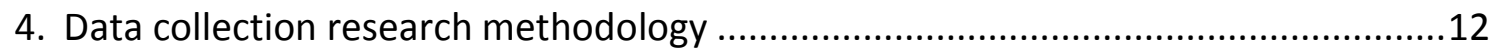

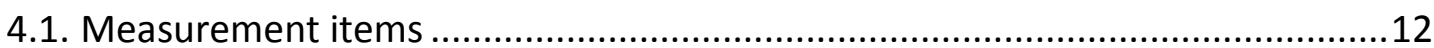

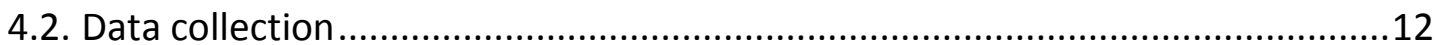

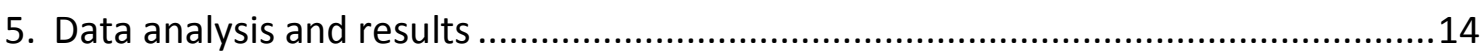

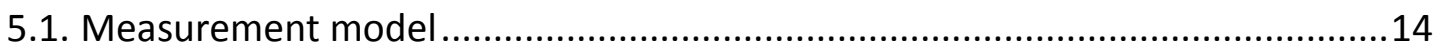

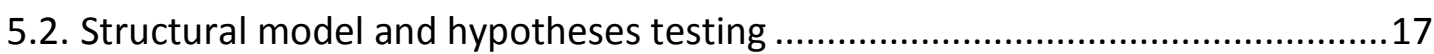

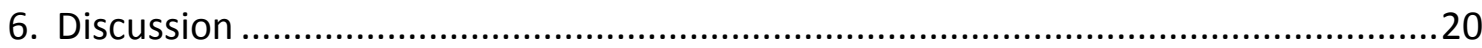

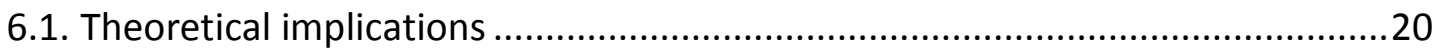

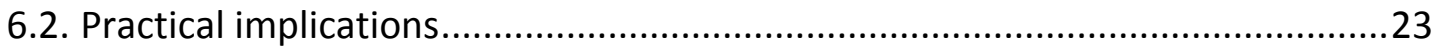

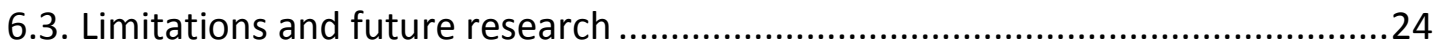

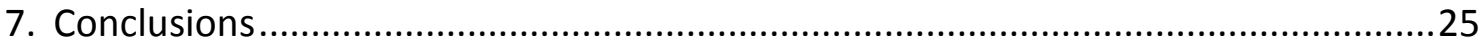

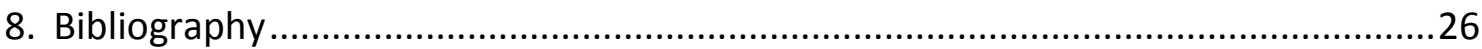

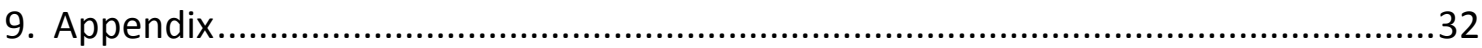

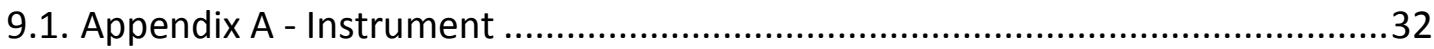

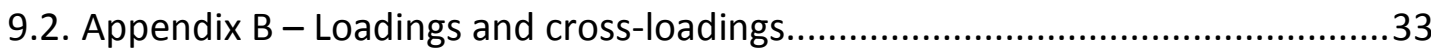




\section{LIST OF FIGURES}

Figure 1. Extended unified theory of acceptance and use of technology (UTAUT2) model. .... 5

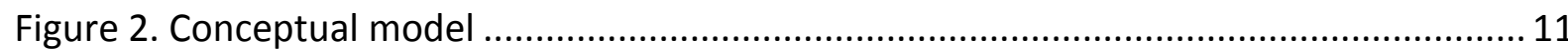




\section{LIST OF TABLES}

Table 1. ICTs and support.

Table 2. Summary of previous research on personality traits in technology adoption context published on peer review journals....

Table 3 Sample characteristics 13

Table 4. AVE, CR, Cronbach's alpha and loadings 15

Table 5. Fornell-Larcker Criterion. 16

Table 6. VIF, outer weights and outer loadings 17

Table 7. Structural model with path coefficients and R2 for UTAUT2 model, Personality model and UTAUT2 + Personality model ................................................................... 18

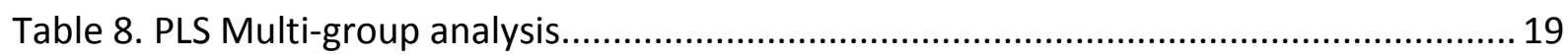

Table 9. Significant ICT adoption factors and country differences ...................................... 23 


\section{LIST OF ABBREVIATIONS AND ACRONYMS}

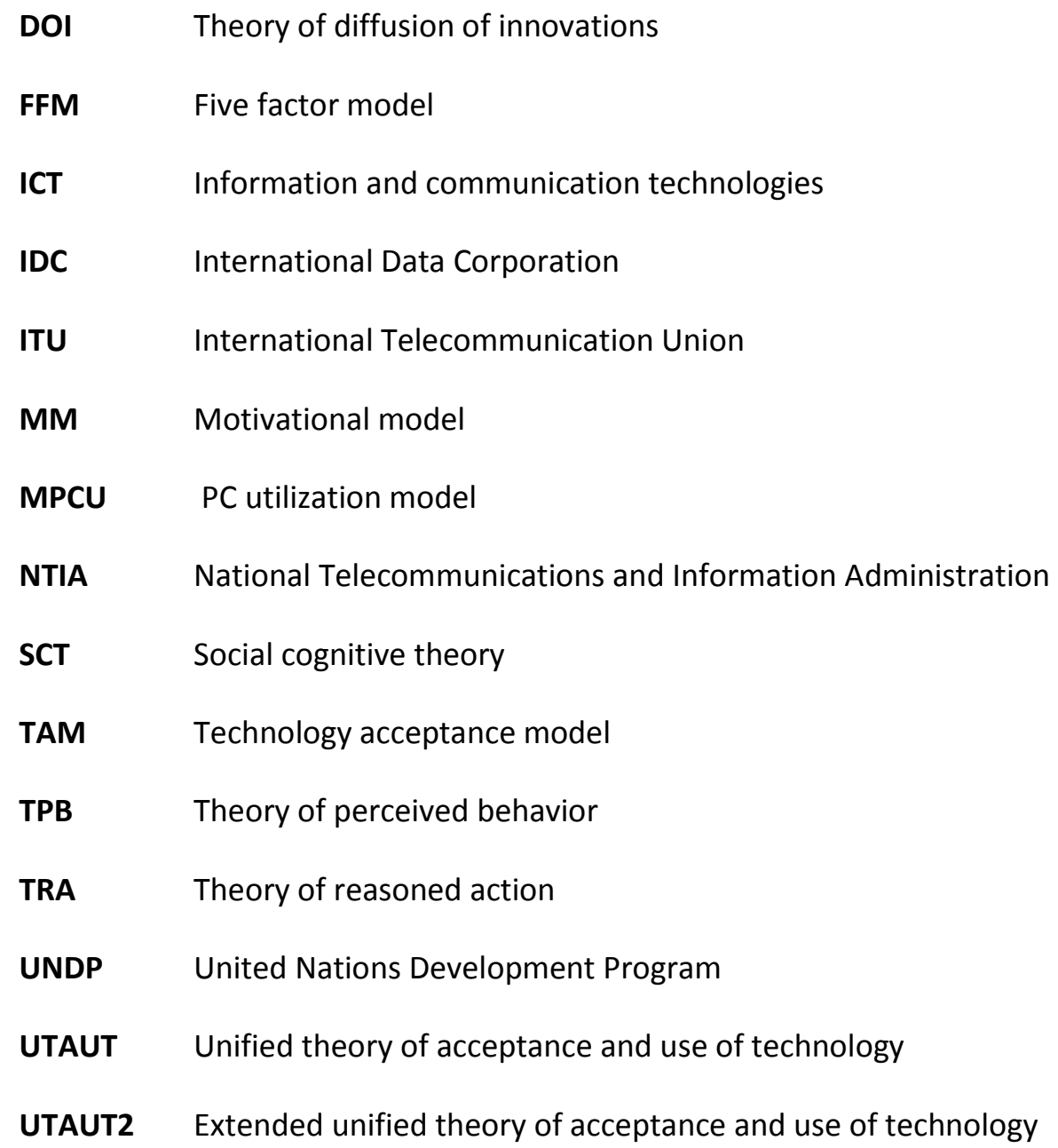




\section{INTRODUCTION}

Information and communication technologies (ICTs) become more integrated across all sectors of economy and society (European Commission, 2015). Research has shown that investment in ICTs is associated with economic benefits, such as higher productivity, lower costs, new economic opportunities, job creation, innovation and increased trade. ICT also help provide better services in health and education, and strengthen social cohesion (World Bank, 2014). According to the International Telecommunications Union (ITU, 2014), ICTs will continue to play a major role in facilitating access to information, knowledge and key services. As more and more people join the information society and high-speed communication networks, the tracking and measurement of ICTs developments becomes even more relevant. Continuous monitoring and measurement of ICTs developments will help to identify progress and gaps.

The advancement and diffusion of technologies has evolved at historical rates. For example, global internet penetration grew from 6.5\% in 2000 to $47 \%$ in 2016 and many developed countries are experiencing penetration rates of more than $90 \%$ (ITU, 2015, 2016). The ongoing development of ICTs in all its forms and applications is driving radical change in our lives, with the constant creation of new products and services, new ways of conducting business, new markets and investment opportunities, new social and cultural expressions and new channels for citizens and government to interact $(O E C D, 2003)$. Hence, the continued existence of a digital divide, however defined, is an obstacle to any agenda of social inclusion. If societies are today partly, and will in the future more or less be completely structured around ICTs, then the demand of economic efficiency as well as social and political equity, require that no social group finds itself excluded from participation (Alvares et al., 2014). Hence, understanding how ICTs are adopted can help in reducing the digital divide.

This study explores the digital divide phenomenon from the perspective of individual ICTs acceptance. It digs into the individual pattern of behavioral intention and usage behavior of a set of ICTs. Therefore, its main contributions are threefold: Firstly, it adds to the current knowledge on digital divide by checking the phenomenon in a broader context at the individual level. Secondly, the study proposes a theoretical model for the acceptance of the ICTs at the individual level that combines the extended unified theory of acceptance and use of technology (UTAUT2) (Venkatesh, Thong, \& Xu, 2012) with the big five personality traits (Costa \& McCrae, 1992; Digman, 1990). By doing so, it provides insights on factors affecting the adoption of technologies and explores if and how the big five personality traits (openness, extraversion, agreeableness, conscientiousness and neuroticism) influence usage behavior, empirically testing its applicability in the context of Eastern and Western European countries. Thirdly, it aims at identifying what factors in the proposed model differ the most across cultures (in the context of Eastern and Western European countries).

The remainder of the paper is structured as follows. Firstly, a theoretical background of the problem is presented, introducing the concept of digital divide, previous research on the phenomenon, overview of adoption models at the individual level and personality traits concept. Secondly, a research model is proposed and hypotheses are developed. Thirdly, the research method is described and study results are exhibited. Finally, a discussion, implications and conclusions are presented. 


\section{THEORETICAL BACKGROUND}

\subsection{The Digital Divide}

The digital divide is a complex phenomenon that hinges on many different factors (Hilbert, 2011). Initially, the digital divide was defined as the gap between "those who have access to digital ICT and those who do not" (OECD, 2001). Studies conducted in the 1990s were primarily concerned with issues surrounding access, where access was measured in terms of having a computer at home that connects to the internet. Representative surveys of this period that were focused on the number and categories of people with access to a computer and Internet, are the first "Falling Through the Net" reports from the US Department of Commerce's National Telecommunications and Information Administration (NTIA) (US Department of Commerce, 1995, 1998, 1999). However, since the year 2002, the physical access among the different categories of people in the developed countries started to decline (US Department of Commerce, 2000). Therefore, an increasing number of researchers suggested reframing the overly technical concept of the digital divide, to go beyond access and pay more attention to social, psychological and cultural backgrounds (van Dijk, 2006). DiMaggio, et.al. (2004) were among the first to expand the context of digital divide by referring to not just differences in access (later labeled as the first-order digital divide), but autonomy of use, skill, social support and the purposes for which the technology is employed, labeled as the secondorder digital divide. Indeed, as the majority of the participants in any social system have obtained access to a technology, the second order divide starts to become more important than the first order divide (Dewan \& Riggins, 2005).

The digital divide is, therefore, a multidimensional and complex phenomenon that extends beyond access to technology and incorporates several perspectives. Previous research on issues related to the digital divide has been conducted at three levels of analysis: the individual level, organizational level, and global level (Dewan \& Riggins, 2005). In this paper the phenomenon is analyzed at the individual level and the concept 'digital divide' refers to the difference in usage of ICTs, and correspondingly to information content and any socio-economic opportunities related to it.

In terms of indicators used to measure the digital divide, these have changed over time due to the changing characteristics and introduction of new ICTs applications. Over time international institutions tracking digital development have been introducing new indicators to measure the information society. While indicators initially concentrated on access and connectivity issues, their scope has later been extended to cover new product groups and means of delivering communication technologies to end-users (Eurostat, 2013). For example, in its latest module examining the information society, Eurostat's statistics includes the use of cloud computing services. Studies have examined digital divide in the context of various technologies, e.g., there are studies that focus on differences in Internet use (Brandtzæg, Heim, \& Karahasanović, 2011; Zhang, 2013), mobile devices adoption (see, e.g., Lee, Park, \& Hwang, 2015; Magsamen-Conrad, Upadhyaya, Joa, \& Dowd, 2015; Shim, You, Lee, \& Go, 2015), advanced e-services (see, e.g., Akhter, 2003; Chong, Chan, \& Ooi, 2012; Gulati, Williams, \& Yates, 2014; Hung, Chang, \& Kuo, 2013), social networks (Hargittaia \& Hsiehb, 2010), among others. Research in the digital divide has often used variables from international institutions such as the EUROSTAT, the OECD, the World Bank, the United Nations Development Program (UNDP), the International Data Corporation (IDC), and the International Telecommunication 
Union (ITU) to measure the phenomenon. The indicators applied to measure technology use are based on the research literature and are described in Table 1.

Table 1. ICTs and support

\begin{tabular}{|c|c|c|}
\hline Code & ICT Application & Support \\
\hline Int & $\begin{array}{l}\text { Individuals regularly using the } \\
\text { Internet }\end{array}$ & $\begin{array}{l}\text { (Billón, Ezcurra, \& Lera-López, 2008; Cruz-Jesus, } \\
\text { Oliveira, \& Bacao, 2012; Cruz-Jesus, Vicente, Bacao, \& } \\
\text { Oliveira, 2016; Haight, Quan-Haase, \& Corbett, 2014; } \\
\text { María Rosalía Vicente \& López, 2011) }\end{array}$ \\
\hline Mobile & $\begin{array}{l}\text { Individuals accessing the Internet via a } \\
\text { mobile device }\end{array}$ & $\begin{array}{l}\text { (Cruz-Jesus et al., 2016; ITU, 2014; M R Vicente \& López, } \\
\text { 2008; María Rosalía Vicente \& López, 2006) }\end{array}$ \\
\hline eBank & $\begin{array}{l}\text { Individuals using banking services } \\
\text { online }\end{array}$ & $\begin{array}{l}\text { (Cruz-Jesus et al., 2012, 2016; European Commission, } \\
\text { 2010) }\end{array}$ \\
\hline eHealth & $\begin{array}{l}\text { Individuals seeking health-related } \\
\text { information online }\end{array}$ & $\begin{array}{l}\text { (Cruz-Jesus et al., 2012, 2016; European Commission, } \\
\text { 2010) }\end{array}$ \\
\hline eLearn & $\begin{array}{l}\text { Individuals looking for information } \\
\text { about education }\end{array}$ & $\begin{array}{l}\text { (Çilan, Bolat, \& Coşkun, 2009; Cruz-Jesus et al., 2012, } \\
\text { 2016; European Commission, 2010) }\end{array}$ \\
\hline eGov & $\begin{array}{l}\text { Individuals interacting with public } \\
\text { authorities online }\end{array}$ & $\begin{array}{l}\text { (Çilan et al., 2009; Cruz-Jesus et al., 2012, 2016; } \\
\text { European Commission, 2010) }\end{array}$ \\
\hline IntSrc & $\begin{array}{l}\text { Individuals looking for information } \\
\text { about goods and services online }\end{array}$ & (Cruz-Jesus et al., 2012, 2016; Lian \& Yen, 2014) \\
\hline eCom & $\begin{array}{l}\text { Individuals ordering goods or services } \\
\text { online }\end{array}$ & $\begin{array}{l}\text { (Cruz-Jesus et al., 2012, 2016; European Commission, } \\
\text { 2010; Vicente Cuervo \& López Menéndez, 2006) }\end{array}$ \\
\hline eCom_CB & $\begin{array}{l}\text { Individuals ordering goods or services } \\
\text { online, from sellers from other EU } \\
\text { countries }\end{array}$ & (Cruz-Jesus et al., 2016; European Commission, 2013) \\
\hline eCivic & $\begin{array}{l}\text { Individuals active in online public } \\
\text { participation }\end{array}$ & $\begin{array}{l}\text { (Cruz-Jesus et al., 2016; Epstein, Newhart, \& Vernon, } \\
\text { 2014; María Rosalía Vicente \& Novo, 2014; Wattal, } \\
\text { Schuff, \& Mandviwalla, 2010) }\end{array}$ \\
\hline SNS & $\begin{array}{l}\text { Individuals participating in social } \\
\text { networks online (e.g., Facebook, } \\
\text { Twitter) }\end{array}$ & $\begin{array}{l}\text { (Haight et al., 2014; Sato \& Costa-i-Font, 2013; María } \\
\text { Rosalía Vicente \& Novo, 2014) }\end{array}$ \\
\hline Cloud & $\begin{array}{l}\text { Individuals using storage space on the } \\
\text { Internet (Cloud) to save files for } \\
\text { private purposes }\end{array}$ & (European Commission, 2012) \\
\hline
\end{tabular}




\subsection{ADOPTION MODELS AT THE INDIVIDUAL LEVEL}

Several technology acceptance theories and models have been developed and used to better understand the aspects that influence information technology acceptance in terms of behavioral intention (BI) and usage. One of the first frameworks to address technology acceptance is the theory of diffusion of innovations (DOI) (Rogers, 1995), which investigates innovations' characteristics that influence its adoption. These are the theory of reasoned action (TRA), for example, states that an individual's behavioral intentions determine his or her actual behavior. Behavioral intention is in turn determined by the individual's attitude toward this behavior and subjective norms with regard to the performance of this behavior (Fishbein \& Ajzen, 1975). Based on the theory of reasoned action, (Davis, 1989) developed the technology acceptance model (TAM) to find out what factors cause people to accept or reject an information technology on the job. He suggests that perceived usefulness and perceived ease of use are the two most important individual beliefs about using an information technology. The theory of perceived behavior (TPB) is also based on the TRA and developed by Ajzen (1991), who adds a new construct - perceived behavioral control defined as the perceived ease or difficulty of performing the behavior.

Considering the lack of a unified view on technology acceptance theory Venkatesh et al. (2003) combined previous acceptance models and introduced the unified theory of acceptance and use of technology (UTAUT) built on eight previously developed theories: TRA, TAM, the motivational model (MM) (Davis, Bagozzi, \& Warshaw, 1992) TPB, the PC utilization model (MPCU) (Thompson, Higgins, \& Howell, 1991), DOI (Rogers, 1995) and social cognitive theory (SCT) (Compeau \& Higgins, 1995), and an integrated model of technology acceptance and planned behavior (TAM-TPB) (Taylor \& Todd, 1995). The model proposes four constructs: performance expectancy, effort expectancy, social influence, and facilitating conditions. Besides it proposes four moderator variables, that is, gender, age, experience, and voluntariness of use.

Later on Venkatesh et al. (2012) revise the UTAUT and adapt the original model to the context of consumer services, adding three new factors: hedonic motivations, cost, and habit. The model is composed of seven constructs: performance expectancy, effort expectancy, social influence, facilitating conditions, hedonic motivation, price value, and habit (please, see Figure 1). Like in UTAUT there are moderating variables (age, gender, and experience), but the voluntariness is dropped. Experience is proposed to moderate as well the effect of behavioral intention on use. Another change is that UTAUT2 facilitating conditions influence not only actual behavior (like in UTAUT), but also behavioral intention. The construct of habit is also hypothesized to influence both behavioral intention and actual usage. 
Figure 1. Extended unified theory of acceptance and use of technology (UTAUT2) model.

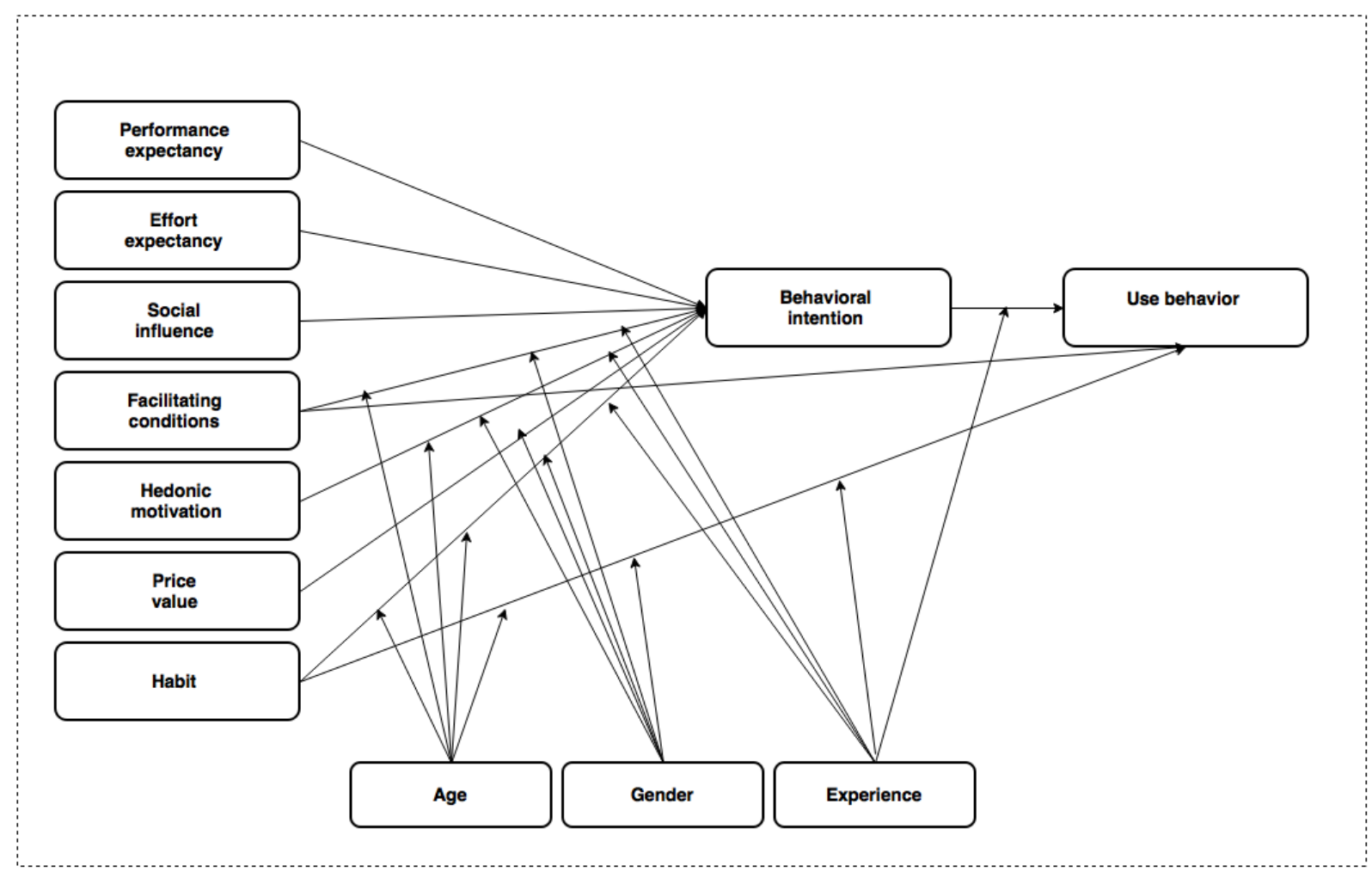

\subsection{PERSONALITY TRAITS}

Personality refers to an individual's unique internal traits (Walczuch \& Lundgren, 2004). Prior research on personality has demonstrated a lot of traits that have been a subject of investigation since 1930, when 4500 descriptive terms have been identified for personality by Allport \& Odbert (1936). Although a universal view on the dimensions of personality lacks, it is widely accepted among psychologists that the domain of personality can be described by five constructs (Barrick, Mount, \& Judge, 2001; Digman, 1990). This theoretical approach to personality classification has become known as the Five Factor Model (FFM) and its dimensions are referred to as the big five. It consists of five broad personality traits, namely, openness, extraversion, agreeableness, conscientiousness and neuroticism. These basic tendencies are inborn and develop throughout one's lifespan, influencing an individual's thoughts, feelings, and actions (Costa, \& McCrae, 1992).

Research in social psychology has shown that personality traits often determine an individual's beliefs and behavior across different aspects of life (Digman, 1990). Studies have tested the role of personality in a variety of contexts, like behavior in trading activities (Kleine, Wagner, \& Weller, 2015), eco-friendly behavior (Fraj \& Martinez, 2006; Kvasova, 2015), social networks use (see e.g., Amichai-Hamburger \& Vinitzky, 2010; Hughes, Rowe, Batey, \& Lee, 2012; Kokkinos, Baltzidis, \& Xynogala, 2016).

There has been a growing interest in personality as an explanatory tool in technology acceptance (Li, Tan, Teo, \& Tan, 2006). Although a number of studies have researched links between personality and technology use (see e.g., Behrenbruch, Söllner, Leimeister, \& Schmidt, 2013; Tang, Chen, Yang, Chung, \& Lee, 2016) this area of research is still scarce. In light of his gap in the 
technology acceptance literature, one of the contributions of this paper is to expand the knowledge in the area and incorporate personality in the UTAUT2 in order to examine if and how personality influences technology adoption. It analyzes the effects of personality not as an external variable that may impact intention and use through the other constructs of UTAUT2, but as directly affecting intention and use.

Table 2 summarizes previous research on personality regarding technology adoption. It shows the research model applied (where applicable), main findings in terms of significant personality predictors and the technology context of the research. Although Information Systems (IS) research has demonstrated the relevance of personality regarding technology adoption behaviors, e.g. within the framework of TAM, the extant research is still scant. Of the illustrative studies shown in table 2, personality traits are examined as having an impact on behavioral intention via other constructs and only one paper (Picazo-Vela, Chou, Melcher, \& Pearson, 2010) hypothesizes a direct effect of personality on behavioral intention. As for the papers where personality is not incorporated in an established technology adoption model, the direct relationship between personality traits and ICT use is examined. Therefore, one of the contributions of the current study is that it hypothesizes direct relationships to both behavioral intention and usage behavior. 
Table 2. Summary of previous research on personality traits in technology adoption context published on peer review journals

\begin{tabular}{|c|c|c|c|}
\hline Reference & Underlying theory/Relationship & Main findings & $\begin{array}{l}\text { Technology } \\
\text { context }\end{array}$ \\
\hline $\begin{array}{l}\text { (Landers \& } \\
\text { Lounsbury, } \\
\text { 2006) }\end{array}$ & $\begin{array}{l}\text { Examines the relationship between } \\
\text { personality traits and Internet use }\end{array}$ & $\begin{array}{l}\text { Internet use was negatively related to } \\
\text { agreeableness, conscientiousness, and extraversion } \\
\text { as well as two narrow traits - optimism and work } \\
\text { drive, and positively related to tough-mindedness }\end{array}$ & Internet use \\
\hline $\begin{array}{l}\text { (Devaraj, } \\
\text { Easley, \& } \\
\text { Grant, 2008) }\end{array}$ & TAM and big five personality traits & $\begin{array}{l}\text { conscientiousness, extraversion, neuroticism and } \\
\text { agreeableness affect perceived usefulness and } \\
\text { subjective norms towards the acceptance and use of } \\
\text { technology }\end{array}$ & $\begin{array}{l}\text { commercial } \\
\text { collaborative } \\
\text { system (e- } \\
\text { project) }\end{array}$ \\
\hline $\begin{array}{l}\text { (Butt \& } \\
\text { Phillips, } \\
\text { 2008) }\end{array}$ & $\begin{array}{l}\text { Examines the relationship between } \\
\text { personality and mobile phone use }\end{array}$ & $\begin{array}{l}\text { agreeableness, extraversion and neuroticism } \\
\text { explain patterns of mobile phone use }\end{array}$ & $\begin{array}{l}\text { mobile } \\
\text { phones use }\end{array}$ \\
\hline $\begin{array}{l}\text { (Hunsinger, } \\
\text { Poirier, \& } \\
\text { Feldman, } \\
\text { 2008) }\end{array}$ & $\begin{array}{l}\text { Examines the relationship between } \\
\text { personality and attitudes towards } \\
\text { Individual response technology } \\
\text { (IRT) use }\end{array}$ & $\begin{array}{l}\text { extraversion and conscientiousness are positively } \\
\text { related to IRT use }\end{array}$ & $\begin{array}{l}\text { Individual } \\
\text { response } \\
\text { technology }\end{array}$ \\
\hline $\begin{array}{l}\text { (Picazo-Vela } \\
\text { et al., 2010) }\end{array}$ & $\begin{array}{l}\text { TPB and big five personality } \\
\text { framework }\end{array}$ & $\begin{array}{l}\text { neuroticism and conscientiousness are significant } \\
\text { predictors of an individual's intention to provide an } \\
\text { online review }\end{array}$ & $\begin{array}{l}\text { providing an } \\
\text { online review }\end{array}$ \\
\hline $\begin{array}{l}\text { (Amichai- } \\
\text { Hamburger \& } \\
\text { Vinitzky, } \\
\text { 2010) }\end{array}$ & $\begin{array}{l}\text { Examines how personality is } \\
\text { related to behavior on Facebook }\end{array}$ & $\begin{array}{l}\text { each of the personality factors examined is relevant } \\
\text { to aspects of Facebook use }\end{array}$ & Facebook \\
\hline $\begin{array}{l}\text { (Svendsen, } \\
\text { Johnsen, } \\
\text { Almås- } \\
\text { Sørensen, \& } \\
\text { Vittersø, } \\
\text { 2011) }\end{array}$ & $\begin{array}{l}\text { TAM and the big five personality } \\
\text { traits }\end{array}$ & $\begin{array}{l}\text { extraversion has significant, positive relations to } \mathrm{BI} \text {; } \\
\text { neuroticism is related to } \mathrm{Bl} \text {; openness to experience } \\
\text { is significantly and positively related to perceived } \\
\text { ease of use, but does not influence } \mathrm{BI}\end{array}$ & $\begin{array}{l}\text { a software } \\
\text { tool designed } \\
\text { to take care of } \\
\text { digital } \\
\text { contents, like } \\
\text { images, music } \\
\text { and files }\end{array}$ \\
\hline $\begin{array}{l}\text { (Terzis, } \\
\text { Moridis, \& } \\
\text { Economides, } \\
\text { 2012) }\end{array}$ & $\begin{array}{l}\text { Computer Based Assessment } \\
\text { Acceptance Model (CBAAM) and } \\
\text { big five personality framework }\end{array}$ & $\begin{array}{l}\text { neuroticism has significant negative effect on } \\
\text { perceived usefulness and on goal expectancy; } \\
\text { agreeableness determines social influence and } \\
\text { perceived ease of use, conscientiousness defines } \\
\text { perceived ease of use; extroversion and openness } \\
\text { explain perceived importance }\end{array}$ & $\begin{array}{l}\text { computer } \\
\text { based } \\
\text { assessment }\end{array}$ \\
\hline $\begin{array}{l}\text { (Xu, Frey, } \\
\text { Fleisch, \& } \\
\text { llic, 2016) }\end{array}$ & $\begin{array}{l}\text { Examines impact of the big five } \\
\text { personality traits on mobile } \\
\text { applications use }\end{array}$ & $\begin{array}{l}\text { personality traits have significant impact on the } \\
\text { adoption of different types of mobile apps }\end{array}$ & mobile apps \\
\hline $\begin{array}{l}\text { (Tang et al., } \\
\text { 2016) }\end{array}$ & $\begin{array}{l}\text { Examines the relationship between } \\
\text { the big five personality traits on } \\
\text { Facebook use }\end{array}$ & $\begin{array}{l}\text { agreeableness, conscientiousness, and neuroticism } \\
\text { were negatively associated with Facebook addiction }\end{array}$ & Facebook \\
\hline $\begin{array}{l}\text { (Noë, } \\
\text { Whitaker, } \\
\text { Chorley, \& } \\
\text { Pollet, 2016) }\end{array}$ & $\begin{array}{l}\text { Examines relationship between } \\
\text { personality and online check-ins in } \\
\text { common locations by location- } \\
\text { based social networks (LBSNs) }\end{array}$ & $\begin{array}{l}\text { conscientious, open or agreeable people tended to } \\
\text { have checked-in locations in common; neurotic } \\
\text { individuals did not tend to have locations in common }\end{array}$ & $\begin{array}{l}\text { location- } \\
\text { based social } \\
\text { networks } \\
\text { (LBSNs):Four } \\
\text { square }\end{array}$ \\
\hline
\end{tabular}




\section{RESEARCH MODEL AND HYPOTHESES}

The research model used in this study combines the UTAUT2 with the big five theory of personality traits. The UTAUT2 model has shown to improve the variation explained in behavioral intention and usage behavior compared to UTAUT (Venkatesh et al., 2012) and is hence chosen for this study. Having in mind that personality may affect individual's adoption of ICT as shown in Table 1 , personality traits are also used in our research model.

Performance expectancy is the degree to which an individual believes that using a technology provides benefits in performing certain activities and is considered to be similar to the perceived usefulness of TAM (Venkatesh et al., 2003). The performance expectancy construct has proved to be the strongest predictor of use intention (Venkatesh et al., 2003, 2012). In the context of the predefined set of ICTs, we believe that individuals will tend to adopt technologies due to perceived performance improvements and benefits. Therefore, we hypothesize that:

$\mathrm{H1}$ : The impact of performance expectancy (PE) on behavioral intention (BI) will be positive.

Effort expectancy is the degree of ease associated with the use of technologies (Venkatesh et al., 2003) and it has proven to be a significant predictor of intention to use ICTs (Venkatesh et al., 2012). If a system is perceived as an easy to use, there is a higher likelihood that it will be accepted by users (Davis, 1989). Hence, in the context of ICT, we believe this construct will play a key role. As demonstrated by Venkatesh et al. $(2003,2012)$, effort expectancy is an ICT key driver as it positively convinces individuals to overcome ICT complexity. Therefore, we hypothesize:

$\mathrm{H} 2$ : The impact of effort expectancy (EE) on behavioral intention (BI) will be positive

Social influence is the extent to which individuals perceive that others, especially friends and family, believe they should use technologies (Venkatesh et al., 2003, 2012). It is considered to be similar to subjective norm of TRA. It has been validated as a significant predictor of intention (Venkatesh et al., 2003, 2012). Technologies have become an indispensable way for individuals to create new ways to communicate, aggregate, and share information. Therefore, information and opinions obtained through social network usage for example, might affect and individual's intention to adopt a certain technology and we hypothesize the following:

$\mathrm{H} 3$ : The impact of social influence (SI) on behavioral intention (BI) will be positive.

Facilitating conditions refers to how people believe that technical infrastructures exist to help them to use the system whenever necessary (Venkatesh et al., 2003). ICT usage is related to having digital skills varying from basic ones (low-level individual know-how for elementary uses of ICT) to more complex capabilities (higher-level literacy for creative engagement in digital media and ability for ICT-mediated interaction) (Mendonça, Crespo, \& Simões, 2015). A lack of such skills would make individuals perceive a difficulty in ICT use, so the presence of a favorable set of facilitating conditions would positively influence users in their decision to adopt ICTs. Therefore, we hypothesize:

$\mathrm{H} 4 \mathrm{a}$ : The impact of facilitating conditions (FC) on behavioral intention (BI) will be positive. $\mathrm{H} 4 \mathrm{~b}$ : The impact of facilitating conditions (FC) on usage behavior (UB) will be positive. 
Hedonic motivation is defined as the fun or pleasure derived from using a technology (Venkatesh et al., 2012). It has been demonstrated that hedonic motivation is a relevant predictor of technology adoption (Childers, Carr, Joann, \& Carson, 2001; Heijden, 2004). Therefore, we hypothesize:

H5: The impact of hedonic motivation (HM) on behavioral intention (BI) will be positive.

Price value is the consumers' cognitive trade-off between the perceived benefits of using a technology and the monetary cost of using it (Venkatesh et al., 2012). The concept of price value is defined as "consumers' cognitive trade-off between the perceived benefits of the applications and the monetary cost for using them" (Dodds, Monroe, \& Grewal, 1991). In the context of the following study, the respondents bare the cost of the ICTs in question, like device costs or fees to service provider companies. Therefore, we hypothesize:

H6: The impact of price value (PV) on behavioral intention (BI) will be positive.

Habit reflects the multiple results of previous experiences (Venkatesh et al., 2012). UTAUT2 adopts the concept of habit from (Limayem, Hirt, \& Cheung, 2007), who consider habit as a selfreported perception and show that habit has a direct effect on technology use. Once a behavior becomes a habit, it becomes automatic and is practiced without conscious decision (Ouellette \& Wood, 1998). Therefore, when habit is stronger individuals would rely more on their habit rather than external information and conscious decisions Therefore,

H7a: The impact of habit (HB) on behavioral intention (BI) will be positive.

H7b: The impact of habit (HB) on usage behavior (UB) will be positive.

UTAUT2 is consistent with previous models and maintains that behavioral intention has a substantial influence on technology use (Venkatesh et al., 2003). Therefore, it can be postulated that:

H8: The impact of behavioral intention (BI) on usage behavior (UB) will be positive.

As for those constructs originated from personality traits, we have:

Openness is one of the big five personality traits and represents one's receptivity to new ideas and experiences (Korukonda, 2007). It is a characteristic of individuals who have broad interests, seek novelty, who are creative, original, curious, flexible, adventurous and non-conformists (Li et al., 2006). Furthermore, Korukonda (2007) found out that openness to experience results into lower levels of computer anxiety and McElroy et.al. (2007) showed that open people use Internet more intensively. Therefore, as individuals who score high on openness are non-conformists and experimentalist in nature, we hypothesize:

H9a: Openness to experience (OPE) will positively affect behavioral intention (BI)

H9b: Openness to experience (OPE) will positively affect usage behavior (UB)

In general extraverts are adventurous, sociable and talkative, whereas introverts are typically quiet and shy (Costa, \& McCrae, 1992). Those high in extraversion naturally care about their image, have larger social networks and like presenting themselves to others. It is more likely that those who score high on extraversion are more active on social networks and similar technologies, therefore 
having bigger information exposure to new technologies due to bigger social networks. Besides, other characteristics of extraverts are dominance and ambition (Judge, Higgins, Thoresen, \& Barrick, 1999), implying that extraverts may consider advantages and gains from technology adoptions as more important than introverts would.

H10a: Extraversion (EXS) will positively affect behavioral intention (BI)

H10b: Extraversion (EXS) will positively affect usage behavior (UB)

The personality trait agreeableness refers to the level of empathy, compassion, warmth and generosity of an individual (Costa, \& McCrae, 1992). Individuals that score high on agreeableness, exhibit lower level of computer anxiety (Korukonda, 2007). Besides, more agreeable individuals are more likely to relate to technology beliefs when the technology is related to collaboration and cooperation (Devaraj et al., 2008) and tend to build trust in service providers more easily in exchange for the service providers' trust in them (Walczuch \& Lundgren, 2004). Therefore, agreeable people are more likely to build positive beliefs about technology adoption and we hypothesize that:

H11a: Agreeableness (AGR) will positively affect behavioral intention (BI)

H11b: Agreeableness (AGR) will positively affect usage behavior (UB)

Conscientious people are better organized and efficient in carrying out tasks, self-discipline is a major characteristic of a conscientious person (Costa, \& McCrae, 1992). Individuals that score high on conscientiousness are self-motivated, achievement-oriented, systematic and task-oriented (Barrick, 2001). Thus, it is likely that more conscientious people would use technologies more to achieve goals, cooperate with others, and obtain information. Therefore, we hypothesize:

H12a: Conscientiousness (CON) will positively affect behavioral intention (BI)

H12b: Conscientiousness (CON) will positively affect usage behavior (UB)

Individuals who score high on Neuroticism are considered to be more sensitive and nervous with a propensity to worry (Costa, \& McCrae, 1992). Neurotic people are less able to control impulses, hardly cope with stress, and respond emotionally to situations that would not influence most people (McCrae \& John, 1992). It has also been shown that neurotic individuals show higher levels of computer anxiety (Korukonda, 2007). Therefore, those who score high on neuroticism tend to worry that things go wrong easily and regard technologies as stressful. So, we hypothesize that:

H13a: Neuroticism (NEU) will negatively affect behavioral intention (BI)

H13b: Neuroticism (NEU) will negatively affect usage behavior (UB)

In terms of demographic variables, the model includes sex and age. Although some studies have shown that one gender tend to use technologies more than the other, over time research has demonstrated that this gap is closing in a broader context of technology use(Lee et al., 2015). In the context of the numerous ICTs used in this study, we hypothesize that:

H14a: Sex will have no impact on behavioral intention (BI)

H14b: Sex will have no impact on usage behavior (UB)

Generation differences have been studied in several technology adoption papers. Age has proven to be a significant predictor in intention and usage in the context of technology use (see e.g., 
Lian \& Yen, 2014; Magsamen-Conrad et al., 2015; Niehaves \& Plattfaut, 2013). Therefore, we hypothesize:

H15a: Age will negatively affect behavioral intention (BI)

H15b: Age will negatively affect usage behavior (UB)

The proposed conceptual model applied in this study was built on the above listed hypotheses and is shown in Figure 2.

Figure 2. Conceptual model

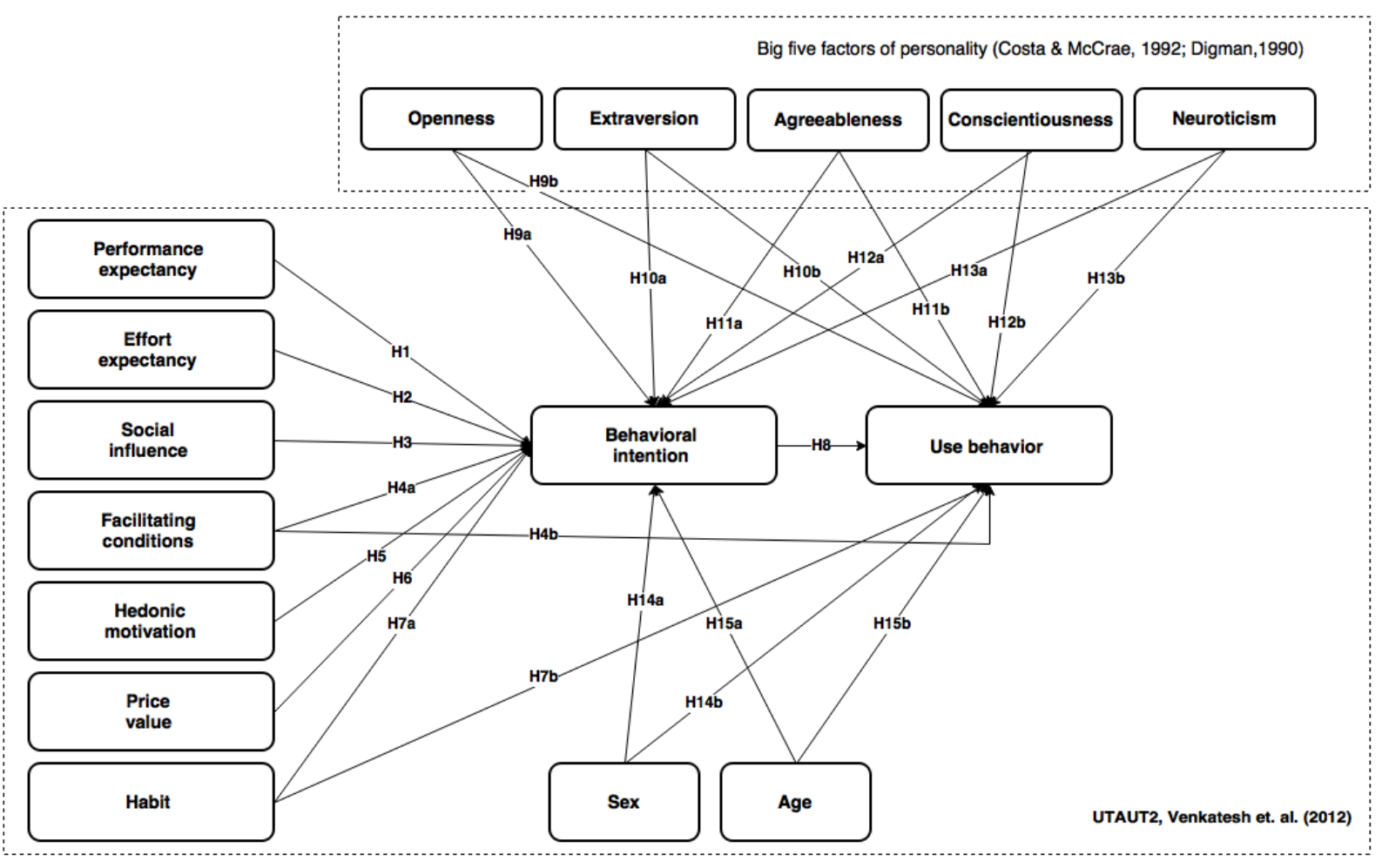




\section{DATA COLLECTION RESEARCH METHODOLOGY}

\subsection{MeAsurement itemS}

All items used to measure the model constructs were adapted from the literature with slight modifications to fit the context of the ICT in question. PE, EE, SI, FC and $\mathrm{BI}$ were adopted from (Venkatesh et al., 2003, 2012), HM, PV and HB from (Venkatesh et al., 2012). As for the personality traits, they were operationalized using a short 20-item version of the 50 -item international personality item pool - five-factor model measure - the mini-IPIP developed by Donnellan et al. (2006). This scale showed convergent, discriminant, and criterion-related validity with other big five measures (Cooper, Smillie, \& Corr, 2010). The advantages of shortened versions of questionnaires include low cost and the short time that it takes to fill them, which makes it possible to include personality measurement in studies whose time is limited, such as those conducted online (Gosling, Rentfrow, \& Swann, 2003). Moreover, four socio-demographic questions related to gender, age, income and professional status were included in the questions.

Most items were measured using seven-point range scales, ranging from totally disagree (1) to totally agree (7). Behavioral intention (BI) was measured by asking respondents about their intentions and plans to use the technology in the future. Personality traits were measured on a seven-point range scale, ranging from very inaccurate (1) to very accurate (7). Usage behavior was measured by asking respondents about their frequency of use of a set of ICTs, ranging from (1) never to (7) many times per day. Age was measured in years. Gender was coded using a 0 or 1 dummy variable where 1 represented women. All constructs were modelled using reflective indicators, except for usage behavior, which was measured by formative indicators. The items for all constructs are included in the Appendix A.

\subsection{DATA COLLECTION}

The questionnaire drawn upon the literature was initially developed in English. The English questionnaire was then translated to Bulgarian and Portuguese respectively by professional native translators. An online questionnaire survey approach was employed. The online questionnaire was send via email to alumni university group in Bulgaria and Portugal respectively. Participation in the survey was voluntarily.

Initially, a pilot study was conducted to test the measurement instrument. Its purpose was to verify the reliability and validity of the measurement scales and check whether the interpretation and answering of the questions was clear to respondents. The pilot survey was answered by 30 respondents, confirming preliminary validity and reliability of the measurement instrument. All items were kept, few were slightly modified to avoid ambiguity issues and ensure clear interpretation.

Data was collected in Bulgaria and Portugal in June - July 2016. In June 2016 a survey was addressed to 2,362 (976 in Bulgaria and in 1386 Portugal). Although some cultural differences in the two audiences addressed were expected, it was reasonable to assume that the two samples were compatible in terms of background and work experience. The total number of complete answers received was 498 (254 for Bulgaria and 244 for Portugal). Hence, the initial response rates were 26.1 
\% in Bulgaria and $17.6 \%$ in Portugal. After removing all incomplete answers, the final number of valid answers was 245 (Bulgaria) and 229 (Portugal) respectively. Therefore, the total sample has 474 valid answers.

Table 3 shows sample characteristics for the total sample, as well as for the Bulgarian and Portuguese samples. Referring to the total sample, the split between male and female participants is respectively $50.8 \%$ vs $49.2 \%$, representing a sample almost equally distributed by gender, with a marginal surplus of men. The largest group of respondents belongs to the 25-34 age group (56.3\%), which is also the largest group in the subsamples per country. It can be noted that while in Bulgaria there are representatives from the last two age groups (55-64 and $65+)$ corresponding to $6.1 \%$ and $4.1 \%$, for the Portuguese sample the participation of these age groups amounts to $0.4 \%$ and $0 \%$. The majority of respondents have reported to be employed (70.0\%).

Table 3 Sample characteristics

\begin{tabular}{|c|c|c|c|c|c|c|c|}
\hline \multirow{2}{*}{ Measure } & \multirow[b]{2}{*}{ Value } & \multicolumn{2}{|c|}{ Total Sample } & \multicolumn{2}{|c|}{ Bulgaria } & \multicolumn{2}{|c|}{ Portugal } \\
\hline & & $\%$ & Frequency & $\%$ & Frequency & $\%$ & Frequency \\
\hline \multirow[t]{2}{*}{ Gender } & Male & $50.8 \%$ & 241 & $54.3 \%$ & 133 & $47.2 \%$ & 108 \\
\hline & Female & $49.2 \%$ & 233 & $45.7 \%$ & 112 & $52.8 \%$ & 121 \\
\hline \multirow[t]{6}{*}{ Age } & $18-24$ & $22.4 \%$ & 106 & $20.4 \%$ & 50 & $24.5 \%$ & 56 \\
\hline & $25-34$ & $56.3 \%$ & 267 & $57.1 \%$ & 140 & $55.5 \%$ & 127 \\
\hline & $35-44$ & $10.3 \%$ & 49 & $8.2 \%$ & 20 & $12.7 \%$ & 29 \\
\hline & $45-54$ & $5.5 \%$ & 26 & $4.1 \%$ & 10 & $7.0 \%$ & 16 \\
\hline & $55-64$ & $3.4 \%$ & 16 & $6.1 \%$ & 15 & $0.4 \%$ & 1 \\
\hline & $65+$ & $2.1 \%$ & 10 & $4.1 \%$ & 10 & $0.0 \%$ & 0 \\
\hline \multirow[t]{8}{*}{ Income } & less than 500 EUR & $3.6 \%$ & 17 & $5.3 \%$ & 13 & $1.7 \%$ & 4 \\
\hline & between 500 and 1000 EUR & $23.2 \%$ & 110 & $29.0 \%$ & 71 & $17.0 \%$ & 39 \\
\hline & between 1000 and 1500 EUR & $34.0 \%$ & 161 & $41.6 \%$ & 102 & $25.8 \%$ & 59 \\
\hline & between 1500 and 2000 EUR & $14.8 \%$ & 70 & $13.1 \%$ & 32 & $16.6 \%$ & 38 \\
\hline & between 2000 and 2500 EUR & $9.7 \%$ & 46 & $3.3 \%$ & 8 & $16.6 \%$ & 38 \\
\hline & between 2500 and 3000 EUR & $3.4 \%$ & 16 & $1.2 \%$ & 3 & $5.7 \%$ & 13 \\
\hline & more than 3000 EUR & $6.3 \%$ & 30 & $4.1 \%$ & 10 & $8.7 \%$ & 20 \\
\hline & $\begin{array}{l}\text { Don't know / Don't want to } \\
\text { answer }\end{array}$ & $5.1 \%$ & 24 & $2.4 \%$ & 6 & $7.9 \%$ & 18 \\
\hline \multirow{5}{*}{$\begin{array}{l}\text { Professional } \\
\text { status }\end{array}$} & Employed or Self Employed & $70.0 \%$ & 332 & $65.3 \%$ & 160 & $75.1 \%$ & 172 \\
\hline & Unemployed & $2.5 \%$ & 12 & $2.4 \%$ & 6 & $2.6 \%$ & 6 \\
\hline & Retired & $3.8 \%$ & 18 & $7.3 \%$ & 18 & $0.0 \%$ & 0 \\
\hline & Student & $22.4 \%$ & 106 & $22.9 \%$ & 56 & $21.8 \%$ & 50 \\
\hline & Other & $1.3 \%$ & 6 & $2.0 \%$ & 5 & $0.4 \%$ & 1 \\
\hline
\end{tabular}




\section{DATA ANALYSIS AND RESULTS}

In the current study measurement model validation and structural model testing were conducted using partial least squares (PLS), a variance-based structural equation modelling technique. This technique is chosen over the covariance-based structural equation modelling as it is less demanding on the sample size and distribution and allows the use of formatively measured constructs (Henseler, Ringleand, \& Sinkovics, 2009). To assess the measurement and structural model, SmartPLS software was used (Ringle, Wende, \& Becker, 2015).

\subsection{MEASUREMENT MODEL}

The conceptual model has both reflective and formative constructs. First, reflective measures are analyzed for indicator reliability composite reliability, convergent and discriminant validity. Second, formative measures are tested for collinearity issues, significance and relevance of outer weights.

To confirm indicator reliability outer loadings were analyzed. The criteria that all outer loadings should be preferably higher than 0.7 and the ones below 0.4 have to be eliminated has been applied (Churchil, 1979; Henseler et al., 2009). CON2R, NEU1, and NEU3 were dropped due to low outer loadings. All other indicators have outer loadings higher than 0.7, with the exception of EXS4R with an outer loading value of 0.67 , which is on the threshold. Besides, all indicators are statistically significant at 0.05 as illustrated in Table 4 . Therefore, indicator reliability can be confirmed. To assess the construct's reliability, we examined the composite reliability (CR) and Cronbach's alpha (Table 4). The CR and Cronbach's alpha are higher than the cut-off of 0.7. Therefore, both criteria are met and internal consistency is ensured (Hair \& Anderson, 2010). Convergence validity has been validated against the criteria that average variance extracted (AVE) should be higher than 0.5 (Fornell \& Larcker, 1981; Henseler et al., 2009). As shown in Table 4, this criterion is met. 
Table 4. AVE, CR, Cronbach's alpha and loadings

\begin{tabular}{|c|c|c|c|c|c|c|}
\hline Construct & Item & AVE & CR & $\begin{array}{l}\text { Cronbach's } \\
\text { alpha }\end{array}$ & Loading & t-statistics \\
\hline \multirow[t]{4}{*}{ Performance expectancy (PE) } & PE1 & 0.885 & 0.969 & 0.957 & 0.927 & 87.328 \\
\hline & PE2 & & & & 0.948 & 126.739 \\
\hline & PE3 & & & & 0.950 & 121.650 \\
\hline & PE4 & & & & 0.939 & 95.616 \\
\hline \multirow[t]{4}{*}{ Effort expectancy (EE) } & EE1 & 0.890 & 0.970 & 0.959 & 0.944 & 132.026 \\
\hline & EE2 & & & & 0.948 & 161.064 \\
\hline & EE3 & & & & 0.954 & 161.784 \\
\hline & EE4 & & & & 0.928 & 107.588 \\
\hline \multirow[t]{4}{*}{ Social influence (SI) } & Sl1 & 0.740 & 0.919 & 0.881 & 0.883 & 57.239 \\
\hline & $\mathrm{SI} 2$ & & & & 0.899 & 79.907 \\
\hline & $\mathrm{SI} 3$ & & & & 0.742 & 23.065 \\
\hline & $\mathrm{SI} 4$ & & & & 0.908 & 89.059 \\
\hline \multirow[t]{4}{*}{ Facilitating conditions (FC) } & $\mathrm{FC} 1$ & 0.771 & 0.931 & 0.901 & 0.879 & 42.520 \\
\hline & FC2 & & & & 0.893 & 72.156 \\
\hline & FC3 & & & & 0.884 & 50.980 \\
\hline & FC4 & & & & 0.856 & 37.691 \\
\hline \multirow[t]{3}{*}{ Hedonic motivation (HM) } & HM1 & 0.879 & 0.956 & 0.931 & 0.934 & 83.420 \\
\hline & HM2 & & & & 0.948 & 156.223 \\
\hline & HM3 & & & & 0.932 & 89.837 \\
\hline \multirow[t]{3}{*}{ Price value $(\mathrm{PV})$} & PV1 & 0.887 & 0.959 & 0.936 & 0.934 & 96.649 \\
\hline & PV2 & & & & 0.951 & 160.005 \\
\hline & PV3 & & & & 0.941 & 120.878 \\
\hline \multirow[t]{4}{*}{ Habit (HB) } & HB1 & 0.671 & 0.890 & 0.835 & 0.867 & 58.918 \\
\hline & HB2 & & & & 0.715 & 24.084 \\
\hline & HB3 & & & & 0.773 & 27.578 \\
\hline & HB4 & & & & 0.908 & 101.242 \\
\hline \multirow[t]{3}{*}{ Behavioral intention (BI) } & $\mathrm{BI}(\mathrm{I}) 1$ & 0.852 & 0.945 & 0.913 & 0.912 & 78.189 \\
\hline & $\mathrm{BI}(\mathrm{I}) 2$ & & & & 0.899 & 52.195 \\
\hline & $\mathrm{BI}(\mathrm{I}) 3$ & & & & 0.957 & 161.434 \\
\hline \multirow[t]{4}{*}{ Openness (OPE) } & OPE1 & 0.720 & 0.911 & 0.872 & 0.874 & 63.080 \\
\hline & OPE2R & & & & 0.809 & 27.843 \\
\hline & OPE3R & & & & 0.833 & 37.836 \\
\hline & OPE4R & & & & 0.875 & 51.008 \\
\hline \multirow[t]{4}{*}{ Extraversion (EXS) } & EXS1 & 0.681 & 0.893 & 0.892 & 0.952 & 6.850 \\
\hline & EXS2R & & & & 0.731 & 3.976 \\
\hline & EXS3 & & & & 0.915 & 6.268 \\
\hline & EXS4R & & & & 0.669 & 3.217 \\
\hline \multirow[t]{4}{*}{ Agreeableness (AGR) } & AGR1 & 0.814 & 0.946 & 0.924 & 0.919 & 93.174 \\
\hline & AGR2R & & & & 0.910 & 67.299 \\
\hline & AGR3 & & & & 0.873 & 47.139 \\
\hline & AGR4R & & & & 0.906 & 64.774 \\
\hline \multirow[t]{3}{*}{ Conscientiousness (CON) } & CON1 & 0.672 & 0.860 & 0.757 & 0.792 & 4.436 \\
\hline & CON3 & & & & 0.888 & 4.881 \\
\hline & CON4R & & & & 0.775 & 3.885 \\
\hline \multirow[t]{2}{*}{ Neuroticism (NEU) } & NEU2R & 0.822 & 0.903 & 0.786 & 0.886 & 47.795 \\
\hline & NEU4R & & & & 0.927 & 91.614 \\
\hline
\end{tabular}

To evaluate discriminant validity, we applied two criteria - Fornell-Larcker and cross-loadings. First, according to Fornell-Larcker criteria, discriminant validity is supported if the square root of AVE for each construct is greater than its correlation with any other construct (Fornell \& Larcker, 1981). This criterion is met as shown in Table 5. Second, discriminant validity was assessed by examining cross-loadings, all indicators' outer loadings (in bold) on a construct should be higher than its crossloadings (Chin,1998). This is illustrated in Appendix B. Hence, it can be concluded that discriminant validity is supported. 
Table 5. Fornell-Larcker Criterion

\begin{tabular}{|l|c|c|c|c|c|c|c|c|c|c|c|c|c|c|c|c|}
\hline Construct & PE & EE & SI & FC & HM & PV & HB & BI & UB & OPE & EXS & AGR & CON & NEU & Age & Sex \\
\hline PE & $\mathbf{0 . 9 4 1}$ & & & & & & & & & & & & & & & \\
\hline EE & 0.649 & $\mathbf{0 . 9 4 4}$ & & & & & & & & & & & & & & \\
\hline SI & 0.396 & 0.374 & $\mathbf{0 . 8 6 0}$ & & & & & & & & & & & & & \\
\hline FC & 0.700 & 0.701 & 0.399 & $\mathbf{0 . 8 7 8}$ & & & & & & & & & & & & \\
\hline HM & 0.619 & 0.622 & 0.362 & 0.591 & $\mathbf{0 . 9 3 8}$ & & & & & & & & & & & \\
\hline PV & 0.407 & 0.474 & 0.396 & 0.487 & 0.517 & $\mathbf{0 . 9 4 2}$ & & & & & & & & & & \\
\hline HB & 0.575 & 0.555 & 0.503 & 0.566 & 0.517 & 0.420 & $\mathbf{0 . 8 1 9}$ & & & & & & & & & \\
\hline BI & 0.764 & 0.585 & 0.489 & 0.626 & 0.607 & 0.384 & 0.657 & $\mathbf{0 . 9 2 3}$ & & & & & & & & \\
\hline UB & 0.478 & 0.478 & 0.378 & 0.461 & 0.324 & 0.293 & 0.458 & 0.506 & $\mathbf{N A}$ & & & & & & & \\
\hline OPE & 0.426 & 0.471 & 0.266 & 0.432 & 0.279 & 0.268 & 0.342 & 0.428 & 0.610 & $\mathbf{0 . 8 4 8}$ & & & & & & \\
\hline EXS & -0.060 & -0.043 & -0.074 & -0.032 & -0.009 & -0.006 & 0.014 & -0.046 & 0.144 & 0.133 & $\mathbf{0 . 8 2 6}$ & & & & & \\
\hline AGR & 0.255 & 0.262 & 0.328 & 0.275 & 0.234 & 0.201 & 0.239 & 0.308 & 0.397 & 0.375 & -0.226 & $\mathbf{0 . 9 0 2}$ & & & & \\
\hline CON & 0.172 & 0.082 & -0.088 & 0.116 & 0.188 & 0.085 & 0.025 & 0.126 & 0.046 & -0.055 & -0.103 & 0.097 & $\mathbf{0 . 8 2 0}$ & & & \\
\hline NEU & -0.277 & -0.348 & -0.280 & -0.270 & -0.207 & -0.266 & -0.308 & -0.319 & -0.287 & -0.308 & -0.091 & -0.064 & -0.041 & $\mathbf{0 . 9 0 7}$ & & \\
\hline Age & 0.041 & -0.157 & -0.095 & -0.072 & 0.047 & -0.014 & -0.109 & -0.007 & -0.418 & -0.309 & -0.139 & -0.184 & 0.240 & 0.055 & $\mathbf{1 . 0 0 0}$ & \\
\hline Sex & -0.107 & -0.084 & 0.004 & -0.037 & 0.047 & -0.003 & -0.101 & -0.087 & -0.037 & -0.031 & -0.122 & 0.205 & 0.047 & 0.221 & -0.026 & $\mathbf{1 . 0 0 0}$ \\
\hline
\end{tabular}

Notes: Diagonal elements in bold are square root of average variance extracted (AVE); NA - Not Applicable; PE: performance expectancy;

EE: effort expectancy; SI: social influence; FC: facilitating conditions; HM: hedonic motivation; PV: price value; $\mathrm{HB}$ : habit; $\mathrm{BI}$ : behavioral

intention; UB: usage behavior; OPE: openness; EXS: extraversion; AGR: agreeableness: CON: conscientiousness: NEU: neuroticism

Secondly, the construct usage behavior (UB), measured by 12 formative indicators, is analyzed. The evaluation of this construct includes assessing collinearity issues. We apply the variance inflation factor (VIF) measure to check for collinearity. In this case the maximum VIF for all items is way below than the conservative threshold of 5 , thus suggesting no issues of collinearity. Second, the significance and relevance of each indicator's outer weights is checked by means of bootstrapping (5,000 iterations). In Table 6 VIF, outer weights, t-statistics for outer weights and outer loadings are shown. All formative indicators outer weights are significant except for IntSrc, eBank, eCom, eLearn, eGov, eHealth, and eCivic. Referring to these indicators outer loadings, they are all above 0.5 (except eGov, eHealth, and eCivic that were eliminated). Hence, the formative indicators retained are presented in Table 6 . 
Table 6. VIF, outer weights and outer loadings

\begin{tabular}{lllll}
\hline Item & VIF & $\begin{array}{l}\text { Outer } \\
\text { Weights }\end{array}$ & T-Statistics & $\begin{array}{l}\text { Outer } \\
\text { Loadings }\end{array}$ \\
\hline Cloud & 1.842 & 0.113 & 2.044 & 0.678 \\
Int & 1.952 & 0.460 & 4.770 & 0.866 \\
IntSrc & 2.208 & 0.039 & 0.464 & 0.621 \\
Mob & 1.930 & 0.208 & 2.656 & 0.781 \\
SNS & 1.807 & 0.262 & 2.970 & 0.736 \\
eBank & 1.385 & -0.008 & 0.149 & 0.503 \\
eCom & 3.111 & -0.024 & 0.264 & 0.638 \\
eCom_CB & 2.313 & 0.230 & 2.586 & 0.603 \\
eLearn & 1.688 & 0.051 & 0.847 & 0.514 \\
\hline
\end{tabular}

\subsection{STRUCTURAL MODEL AND HYPOTHESES TESTING}

As the measurement model results validate a good construct reliability, indicator reliability, convergent and discriminant validity for reflective measures as well as a validation for formative measures, next we proceed with testing the structural model. First, the three models tested are compared - UTAUT, Personality, UTAUT + Personality. The models are assessed and compared by adjusted $R^{2}$ and path coefficients, all shown in Table 7. To analyze the hypotheses and association between constructs standardized paths coefficients are examined, where path significance levels are analyzed using the bootstrap resampling method (Hair \& Anderson, 2010; Henseler et al., 2009) with 5,000 iterations of resampling (Chin, 1998). Finally, a multi-group analysis is performed to compare the differences at country level.

A comparison of the estimated models reveals that when adding personality to UTAUT2, there is an increase in the adjusted $R^{2}$ on usage, with it being 0.45 for UTAUT2, 0.49 for Personality and 0.56 for UTAUT + Personality. On the other hand, when analyzing behavioral intention, the adjusted $\mathrm{R}^{2}$ for UTAUT2 and UTAUT2 + Personality remains the same (0.68). Therefore, the proposed conceptual model (UTAUT2+Personality) has the highest $R^{2}$ on usage behavior as compared to the other two (UTAUT2 and Personality). Next, the analysis focuses on the model combining UTAUT + Personality.

As it can be seen in the last column of Table 7, the conceptual model explains $69 \%$ of the variation in behavioral intention. Performance expectancy, social influence, hedonic motivation, price value, habit, and openness are found statistically significant in explaining behavioral intention, whereas effort expectancy, facilitating conditions, hedonic motivation, price value, extraversion, agreeableness, conscientiousness and neuroticism are not found to have a statistically significant effect on behavioral intention. Regarding usage behavior significant predictors are habit, behavioral intention, openness, extraversion, agreeableness, and age. Facilitating conditions, conscientiousness, and neuroticism are not statistically significant predictors. Our model explains $57 \%$ of the variation in usage behavior. 
Table 7. Structural model with path coefficients and R2 for UTAUT2 model, Personality model and UTAUT2 + Personality model

\begin{tabular}{|c|c|c|c|}
\hline \multirow{2}{*}{\multicolumn{4}{|c|}{$\begin{array}{l}\text { Behavioral } \\
\text { intention }\end{array}$}} \\
\hline & & & \\
\hline $\mathbf{R}^{2}$ & 0.68 & 0.27 & 0.69 \\
\hline Adj. $R^{2}$ & 0.68 & 0.26 & 0.68 \\
\hline $\begin{array}{l}\text { Performance } \\
\text { expectancy (PE) }\end{array}$ & $0.47^{\star \star \star}$ & & $0.44^{* \star *}$ \\
\hline $\begin{array}{l}\text { Effort expectancy } \\
\text { (EE) }\end{array}$ & -0.002 & & -0.04 \\
\hline $\begin{array}{l}\text { Social Influence } \\
\text { (SI) }\end{array}$ & $0.14^{* * *}$ & & $0.12^{* * *}$ \\
\hline $\begin{array}{l}\text { Facilitating } \\
\text { conditions (FC) }\end{array}$ & 0,05 & & 0.04 \\
\hline $\begin{array}{l}\text { Hedonic } \\
\text { motivation (HM) }\end{array}$ & $0,15^{\star * *}$ & & $0.16^{\star * *}$ \\
\hline Price value (PV) & $-0,06^{*}$ & & $-0.07^{\star *}$ \\
\hline Habit (HB) & $0.24^{* * *}$ & & $0.24^{\star \star \star}$ \\
\hline Openness (OPE) & & $0.32^{\star \star \star}$ & $0.08^{* *}$ \\
\hline Extraversion (EXS) & & -0.06 & -0.01 \\
\hline $\begin{array}{l}\text { Agreeableness } \\
\text { (AGR) }\end{array}$ & & $0.15^{\star \star \star}$ & 0.05 \\
\hline $\begin{array}{l}\text { Conscientiousness } \\
\text { (CON) }\end{array}$ & & $0.11^{* *}$ & 0.02 \\
\hline Neuroticism (NEU) & & $-0.21^{* \star *}$ & -0.05 \\
\hline Sex & -0.02 & & -0.02 \\
\hline Age & 0.007 & & 0.03 \\
\hline Usage Behavior & & & \\
\hline $\mathbf{R}^{2}$ & 0.46 & 0.50 & 0.57 \\
\hline Adj. $R^{2}$ & 0.45 & 0.49 & 0.56 \\
\hline $\begin{array}{l}\text { Facilitating } \\
\text { conditions (FC) }\end{array}$ & $0.15^{\star \star \star}$ & & 0.07 \\
\hline Habit (HB) & $0.13^{*}$ & & $0.10^{* *}$ \\
\hline $\begin{array}{l}\text { Behavioral } \\
\text { intention (BI) }\end{array}$ & $0.33^{\star \star *}$ & $0.29^{\star \star \star}$ & $0.20^{* \star \star}$ \\
\hline Openness (OPE) & & $0.39^{\star \star \star}$ & $0.29^{* * *}$ \\
\hline Extraversion (EXS) & & $0.12^{* *}$ & $0.11^{* *}$ \\
\hline $\begin{array}{l}\text { Agreeableness } \\
\text { (AGR) }\end{array}$ & & $0.19^{\star \star \star}$ & $0.15^{\star \star *}$ \\
\hline $\begin{array}{l}\text { Conscientiousness } \\
\text { (CON) }\end{array}$ & & $0.07^{* *}$ & 0.09 \\
\hline Neuroticism (NEU) & & -0.04 & -0.04 \\
\hline Sex & 0.02 & & -0.02 \\
\hline Age & $-0.39^{* * *}$ & & $-0.29^{\star \star *}$ \\
\hline
\end{tabular}

Next, the analysis proceeds with comparison between Bulgaria and Portugal to detect for country differences. To capture significant differences between the two countries, PLS Multi-group analysis is performed (Henseler et al., 2009). Table 8 summarizes the differences for all relationships in the model between the two countries - Bulgaria and Portugal. As shown in the table, there are several 
Table 8. PLS Multi-group analysis

\begin{tabular}{|c|c|c|c|c|}
\hline & $\begin{array}{l}\text { Path Coefficients-diff } \\
\text { (|Bulgaria - Portugal |) }\end{array}$ & $\begin{array}{l}\text { p-Value (Bulgaria vs } \\
\text { Portugal) }\end{array}$ & $\begin{array}{l}\text { UTAUT2 + } \\
\text { Personality (Bulgaria) }\end{array}$ & $\begin{array}{l}\text { UTAUT2 + } \\
\text { Personality (Portugal) }\end{array}$ \\
\hline $\begin{array}{l}\text { Behavioral } \\
\text { intention } \\
\text { R2 }\end{array}$ & & & 0.73 & 0.71 \\
\hline PE -> BI & 0.179 & 0.049 & $0.554^{\star \star *}$ & $0.375^{\star \star \star}$ \\
\hline $\mathrm{EE}->\mathrm{BI}$ & 0.046 & 0.661 & -0.093 & -0.047 \\
\hline $\mathrm{SI}->\mathrm{BI}$ & 0.091 & 0.875 & 0.071 & $0.162^{* *}$ \\
\hline$F C->B I$ & 0.139 & 0.860 & -0.032 & $0.107^{*}$ \\
\hline $\mathrm{HM}->\mathrm{BI}$ & 0.258 & 0.992 & 0.028 & $0.285^{\star \star *}$ \\
\hline$P V->B I$ & 0.023 & 0.626 & -0.067 & -0.044 \\
\hline $\mathrm{HB}->\mathrm{BI}$ & 0.176 & 0.022 & $0.332^{* \star *}$ & $0.156^{\star * *}$ \\
\hline OPE -> BI & 0.026 & 0.632 & 0.058 & $0.084^{*}$ \\
\hline EXS -> BI & 0.008 & 0.554 & 0.019 & 0.027 \\
\hline AGR $->\mathrm{BI}$ & 0.125 & 0.036 & $0.092^{*}$ & -0.032 \\
\hline $\mathrm{CON}->\mathrm{BI}$ & 0.021 & 0.379 & 0.037 & 0.016 \\
\hline NEU -> BI & 0.171 & 0.993 & $-0.129^{\star *}$ & 0.042 \\
\hline Sex -> BI & 0.068 & 0.123 & 0.063 & 0.022 \\
\hline Age $->\mathrm{BI}$ & 0.041 & 0.244 & 0.006 & -0.062 \\
\hline $\begin{array}{l}\text { Usage } \\
\text { behavior } \\
\text { R2 }\end{array}$ & & & 0.67 & 0.49 \\
\hline FC $->$ UB & 0.022 & 0.586 & 0.068 & 0.091 \\
\hline HB $->$ UB & 0.161 & 0.094 & $0.224^{* * *}$ & 0.063 \\
\hline $\mathrm{BI}->\mathrm{UB}$ & 0.431 & 0.992 & -0.007 & $0.424^{* * *}$ \\
\hline OPE -> UB & 0.164 & 0.082 & $0.328^{* * *}$ & $0.164^{*}$ \\
\hline EXS -> UB & 0.139 & 0.090 & $0.172^{* *}$ & 0.033 \\
\hline AGR $->$ UB & 0.061 & 0.305 & $0.208^{* * *}$ & 0.147 \\
\hline CON -> UB & 0.171 & 0.117 & 0.100 & -0.071 \\
\hline NEU -> UB & 0.104 & 0.169 & -0.024 & -0.128 \\
\hline Sex $->$ UB & 0.015 & 0.554 & $-0.360^{* * *}$ & -0.010 \\
\hline Age $->$ UB & 0.350 & 0.976 & 0.005 & 0.021 \\
\hline
\end{tabular}

Notes: ${ }^{*} \mathrm{p}<0.10 ;{ }^{* *} \mathrm{p}<0.05 ;{ }^{* * *} \mathrm{p}<0.01$; PE: performance expectancy; EE: effort expectancy; SI: social influence; FC: Facilitating conditions; HM: hedonic motivation; PV: price value; HB: Habit; BI: behavioral intention; UB: Usage behavior; OPE: Openness; EXS: Extraversion; AGR: Agreeableness: CON: Conscientiousness: NEU: Neuroticism; p-values in bold show the significant differences between the two countries 


\section{DISCUSSION}

\subsection{THEORETICAL IMPLICATIONS}

Considering the importance of the digital divide phenomenon and the popularity of technology adoption models, one of the contributions of this paper is that it adds a bridge between these two fields by introducing and validating a conceptual model in the context of a broad set of ICTs. By linking personality traits directly to behavioral intention and use, we provide additional support for including individual difference variables in the UTAUT2. The results of the study suggest that by adding personality to UTAUT2, the variation explained in usage behavior increased some 11 p.p. (45\% vs $56 \%$ ). In previous research, personality traits have been incorporated in technology adoption models and their impact on technology adoption has been examined via constructs like usefulness or perceived ease of use (see e.g., Devaraj et al., 2008; Picazo-Vela et al., 2010; Terzis et al., 2012). Therefore, another contribution of the current study is incorporating personality in UTAUT2 and examining direct effects on both behavioral intention (BI) and usage behavior (UB). Moreover, it addresses a call for further research to understand the openness dimension as Devaraj et al. (2008) reveal that openness does not affect intention via other TAM constructs, but find some evidence that certain aspects of personality might have a more direct impact on intention to use technology.

Before discussing the results regarding personality traits, we review UTAUT2 hypotheses, most of which are supported. In line with previous research (Venkatesh et al., 2012), the strongest predictor of intention turns out to be performance expectancy $(P E)$, showing that individuals treat the outcomes of ICT use as important. The impact of behavioral intention (BI) on usage behavior (UB) is also significant, indicating that ICT users are more likely to use technologies if they have the intention to use them. Another significant predictor is social influence (SI), revealing that the decision of technology use is affected by an individual's social environment, like friends and family's opinion. Moreover, hedonic motivation (HM) is a significant predictor of behavioral intention (BI), showing individuals use technologies not only to complete tasks but for entertainment purposes as well. This finding is in line with previous research (Morosan \& DeFranco, 2016; Venkatesh et al., 2012). As expected, habit (HB) has a significant positive effect on both behavioral intention and use, indication that individual's automatic behavior positively influences their intention and use of technologies. As for the demographics, in line with other researchers that found that gender differences were no longer relevant in technology use and adoption in modern and technology-literate societies (Workman, 2014), our study confirmed this hypothesis. However, some caution should be taken as the context of this study is, in the two countries, within the European Union. It seems reasonable to hypothesize that in other (mainly developing) countries, gender may have its influence in ICT acceptance. As expected, age affects technology behaviors such that older individuals tend to use technologies less. Hence, to some extent there may exist an age-related digital divided in these two countries.

Contrary to our expectations, effort expectancy (EE) and facilitating conditions (FC) turn out to be non-significant predictors of technology adoption. A possible explanation behind this might be that as the technologies in question are widely spread, users get used to them more quickly and find them easy to use, therefore, putting less importance on the effort expected and the facilitating conditions (like infrastructure and capabilities). Although price value (PV) has a slight significant effect on intention, it is with a negative sign which is contrary to the relationship hypothesized. This 
finding shows that individuals perceive the financial cost to be higher than the advantages of the technologies in question. A reason behind this might be that individuals in the countries where the model was tested, Bulgaria and Portugal, are more price-sensitive.

Next, the effect of personality traits is discussed. Three out of the five personality traits explored (openness, extraversion, and agreeableness) have a direct effect on either one of the constructs of behavioral intention and usage behavior, or on both. Specifically, openness (OPE) is positively associated with both behavioral intention (BI) and usage behavior (UB), indicating that individuals who are more open are more likely to adopt technologies. Although some papers state openness has no effect on technology use (Behrenbruch et al., 2013; Devaraj et al., 2008), in line with our findings, others have shown that openness positively affects social network usage (Amichai-Hamburger \& Vinitzky, 2010; Hughes et al., 2012) and it is positively correlated with the use of social apps (Butt \& Phillips, 2008; Correa, 2010). As for extraversion (EXS), consistent with previous research, we confirm that extroverts use technologies more than introverts. It has been demonstrated that extraversion positively affects the use of technologies (see e.g., Correa, 2010; Hunsinger et al., 2008; Zhou \& Lu, 2011). Furthermore, the current study reveals that individuals who score high on agreeableness (AGR) tend to build positive beliefs to technology adoption in contrast to more disagreeable people. This finding is in line with previous research indicating that agreeableness is positively associated with technology believes, especially when the outcomes of technology use are related to cooperation, task accomplishment and communication (Butt \& Phillips, 2008; Xu et al., 2016). Although extraversion and agreeableness show a positive relationship with usage behavior (UB) as hypothesized, none of them is a significant predictor of behavioral intention (BI). A possible explanation behind this might be that, although extraverted and agreeable people are more likely to become early adopters, the set of technologies in the context of this study are widely spread and intent of early adoption is weakened and non-significant in this context.

Regarding conscientiousness (CON) and neuroticism (NEU), none of the hypotheses is supported. Thus, whether and individual scores high or low in conscientiousness or neuroticism, this would have no effect on their decision to adopt ICTs. Even though conscientious individuals tend to use ICTs when they believe it would help them be more efficient (Devaraj et al., 2008), studies have shown that conscientious people are less likely to adopt socially-based ICTs (Xu et al., 2016). Similarly, previous research has shown that individuals high in neuroticism tend to reduce their use of Internet due to higher levels of anxiety and stress (Devaraj et al., 2008), but at the same time they tend to spend more time on social and shopping apps ( $\mathrm{Xu}$ et al., 2016). Therefore, a possible explanation behind the insignificance of these predictors might be that the current study encompasses a broader set of ICTs characterized by both efficiency and enjoyment outcomes.

Finally, another contribution of this paper is that it discerns patterns of cross-cultural variability (Eastern versus Western Europe), shows the main drivers for ICT adoption in each of the countries and detects for significant differences (Table 9). The differences appearing among the two countries can be sought behind the way personality traits and culture interact to shape the behavior of individuals, market maturity and the stage of the "online evolution". For example, neuroticism is a significant predictor only in Bulgaria, which can be related to the idea that Latin people are more relaxed and exert less anxiety as compared to Balkan people. As it has been previously shown, anxiety and stress reduce the use of Internet (Devaraj et al., 2008). Moreover, neurotic people are less likely to feel enjoyment and pleasure of technology use (Xu et al., 2016). Therefore, they will 
rather tend to use technologies when the outcome is related to performance gains, which might be related to the observation that hedonic motivation is a significant predictor only in Portugal, whereas in Bulgaria performance expectancy is the strongest driver on behavioral intention. Additionally, while in Bulgaria habit is a significant predictor on both behavioral intention (BI) and usage behavior (UB), indicating that past actions are transformed to usage behavior, in Portugal habit positively affect only intention. As suggested by Ouellette \& Wood (1998), in domains where habits are less likely to develop, usage behavior might be controlled by deliberative reasoning processes, and the effects on usage behavior are mediated by intentions. As for the significance difference in agreeableness, it has been demonstrated by Hofstede (2016) that Bulgarians score high on long term orientations as opposed to Portuguese who score low on this dimension. Therefore, Bulgarians show an ability to adapt traditions easily to changed conditions, indicating a more agreeable mindset, whereas Portuguese view societal change with suspicion.

Moreover, there is no significant impact of social influence on behavioral intention to use in Bulgaria, as opposed to Portugal. This means that views of opinion-makers and of those in a social circle do not significantly affect one's behavioral intention to use. An explanation could be that the utility factor of performance expectancy is the major determinant of behavioral intention in Bulgaria, leaving social influence as a weak explanatory variable. While the relationship between behavioral intention (BI) and usage behavior (UB) is significant in the Portuguese sample, it is not supported in the Bulgarian one. This non-significant relationship can be associated with individuals in Bulgaria poorly estimating their own behavior (Straub, Limayem, \& Karahanna-Evaristo, 1995). As for age being significantly different between the two countries, the reasoning should be sought in the sample characteristics, which is addressed as one of the limitations of the current study in section 6.3. 
Table 9. Significant ICT adoption factors and country differences

\begin{tabular}{|c|c|c|c|c|c|}
\hline Relationship & Hypotheis & $\begin{array}{l}\text { Significance (overall } \\
\text { sample) }\end{array}$ & $\begin{array}{l}\text { Significance } \\
\text { (Bulgaria) }\end{array}$ & $\begin{array}{l}\text { Significance } \\
\text { (Portugal) }\end{array}$ & $\begin{array}{l}\text { Significant } \\
\text { difference }\end{array}$ \\
\hline H1: PE -> BI & positive & $\checkmark$ & $\checkmark$ & $\checkmark$ & $\checkmark$ \\
\hline H2: EE -> BI & positive & & & & \\
\hline H3: SI -> BI & positive & $\checkmark$ & & $\checkmark$ & \\
\hline H4a: FC $\rightarrow$ BI & positive & & & $\checkmark$ & \\
\hline H4b: FC -> UB & positive & & & & \\
\hline H5: HM -> BI & positive & $\checkmark$ & & $\checkmark$ & $\checkmark$ \\
\hline H6: PV -> BI & positive & Supported with (-) sign & & & \\
\hline H7a: HB -> BI & positive & $\checkmark$ & $\checkmark$ & $\checkmark$ & $\checkmark$ \\
\hline H7b: HB -> UB & positive & $\checkmark$ & $\checkmark$ & & \\
\hline H8: $B I$-> UB & positive & $\checkmark$ & & $\checkmark$ & $\checkmark$ \\
\hline H9a: OPE -> BI & positive & $\checkmark$ & & $\checkmark$ & \\
\hline H9b: OPE -> UB & positive & $\checkmark$ & $\checkmark$ & $\checkmark$ & \\
\hline H10a: EXS -> BI & positive & & & & \\
\hline H10b: EXS -> UB & positive & $\checkmark$ & $\checkmark$ & & \\
\hline H11a: AGR -> BI & positive & & $\checkmark$ & & $\checkmark$ \\
\hline H11b: AGR -> UB & positive & $\checkmark$ & $\checkmark$ & & \\
\hline H12a: CON -> BI & positive & & & & \\
\hline H12b: CON -> UB & positive & & & & \\
\hline H13a: NEU -> BI & negative & & $\checkmark$ & & $\checkmark$ \\
\hline H13b: NEU -> UB & negative & & & & \\
\hline H14a: Sex -> BI & no impact & $\checkmark$ & & & \\
\hline H14b: Sex -> UB & no impact & $\checkmark$ & & & \\
\hline H15a: Age $->\mathrm{BI}$ & negative & & & & \\
\hline H15b: Age $->$ UB & negative & $\checkmark$ & & & $\checkmark$ \\
\hline
\end{tabular}

Notes: ${ }^{*} \mathrm{p}<0.10 ;{ }^{* *} \mathrm{p}<0.05 ;{ }^{* * *} \mathrm{p}<0.01$; PE: performance expectancy; EE: effort expectancy; SI: social influence; FC: Facilitating conditions; HM: hedonic motivation; PV: price value; HB: Habit; BI: behavioral intention; UB: Usage behavior; OPE: Openness; EXS: Extraversion; AGR: Agreeableness: CON: Conscientiousness: NEU: Neuroticism

\subsection{Practical implications}

The current study reveals that different personality characteristics have an effect on individuals' intention and use of ICTs. A better understanding of individual differences and how they impact adoption intent and usage behavior would have implications for psychologist, marketeers and policy makers in developing, aligning and designing ICT functionalities and creating proper stimuli in regards to personality differences. For example, more open to experience, extraverted and agreeable people are more likely to become adopters of ICTs. Therefore, personality traits should be considered in applying a more personalized marketing on the targeted audience considering this audience's characteristics instead of mass marketing. In regards to the finding that the PE construct is found to be the strongest one, whereas EE in not significant in influencing the adoption intention, system designers should put emphasis on the applications' functionality and usability from the customers 'perspective rather than designing apps that are easy to access and navigate. Besides that, although young users adapt ICT applications easily, developers should still focus on providing technical support to users who are less technologically advanced. Furthermore, marketing practitioners should focus 
on the real value of their ICT applications by revising their marketing and pricing schemes to attract price-sensitive consumers.

As for the comparison in the two cultural contexts - an Eastern and a Western European country - there are variations in the magnitudes of the impacts of the factors of technology adoption across the two countries. This implies that marketers should consider different marketing strategies when planning to market a technology. For example, in Bulgaria it turns out that performance expectancy is a strong predictor, whereas in Portugal hedonic motivation plays a significant role as well. Therefore, targeting a market in Portugal would mean designing not only useful, but also entertaining technologies. Additionally, habit and neuroticism are significant drivers in Bulgaria, indicating that there should be a focus on trying to constantly reinforce users' habit with value added services and upgrades, as well as promote ICT applications in such a way that neurotic individuals do not see them as threatening and stressful.

\subsection{LIMITATIONS AND FUTURE RESEARCH}

Some limitations must be considered when interpreting the results of the current study. One of the limitations is related to the sampling as most respondents are young workers and students More than $50 \%$ of the respondents in the sample are in the age group of $24-35$ and more than $70 \%$ are students or workers. Future research is thus called to confirm our findings among different age and professional groups. Second, the current study uses the personality traits of five-factor model that encompasses five broad factor of personality. Although it has been recognized by researchers that this framework captures an individual's personality (Costa \& McCrae, 1992; Digman, 1990), other more detailed personality dimensions have shown to have impact in the context of technology use. For example, narrow personality traits, such as optimism and work drive, have been investigated in the context of Internet usage by Landers \& Lounsbury (2006). We focused on the big five personality traits as they have been widely applied in technology adoption studies. However, other personality frameworks may offer additional insights to both technology adoption and personality literature. Third, a further limitation is related to the scale used to measure personality traits, 20-item IPIP, a shorter version that is suitable for online questionnaires as it is time saving and results in a higher response rate. However, a recommendation for future research is to apply a longer and more rigorous version of the big five personality traits. Another limitation is related to the broad set of ICTs in use as personality can affect differently the adoption of ICTs depending on their specific functionalities and characteristics. Therefore, future research is called to focus on examining the impact of personality on more specific types of IS adoption and use.

In addition, personality traits also depend on culture and region. This study only focuses on two European countries. However, these findings need to be tested in other cultures. Therefore, future research can use this model to replicate the study in other cultural contexts. Furthermore, this study is based on cross-sectional data and does not detect changes on the investigated relationships over time. Hence, a longitudinal investigation may provide additional insights of the consistency of the studied effects over time. Lastly, this paper used self-reportsurvey measures, and individuals may be inaccurate when making self-assessment of their personality and usage behavior. 


\section{CONCLUSIONS}

Considering the potential of ICTs and the amount of research on technology adoption in IS literature, this study introduces an innovative conceptual model combining UTAUT2 and the big five factors of personality to get further insight on drivers influencing technology adoption at the individual level. The proposed model was empirically tested in the context of a broad predefined set of ICTs and results were collected in two European countries - Bulgaria and Portugal. In agreement with prior research, it confirmed most of the UTAUT2 hypotheses and revealed that personality has an impact in technology adoption. By adding the big five personality traits to UTAUT2, the personality characteristics of openness, extraversion, and agreeableness were found to be significant predictors in the model proposed and thus increased the predictive power of UTAUT2. In regards to the UTAUT2 constructs, performance expectancy and habit turned out to be the strongest predictors on technology behaviors. Besides, the cross-cultural comparison added further insights on how culture influences the predictors and outcomes of technology use among individuals. 


\section{BIBLIOGRAPHY}

Ajzen, I. (1991). The theory of planned behavior. Organizational Behavior \& Human Decision Processes, 50(2), 179-211.

Akhter, S. H. (2003). Digital divide and purchase intention: Why demographic psychology matters. Journal of Economic Psychology, 24(3), 321-327. http://doi.org/10.1016/S0167-4870(02)00171$\mathrm{X}$

Allport, G. W., \& Odbert, H. S. (1936). Trait names: A psycho-lexical study. Psychological Monographs. http://doi.org/10.1037/h0093360

Alvares, C., Cardoso, G., Dahlgren, P., Erstad, O., Fornäs, J., Golding, P., Xinaris, C. (2014). Media in Europe : New Questions for Research and Policy.

Amichai-Hamburger, Y., \& Vinitzky, G. (2010). Social network use and personality. Computers in Human Behavior, 26(6), 1289-1295. http://doi.org/10.1016/j.chb.2010.03.018

Barrick, M. R., Mount, M. K., \& Judge, T. a. (2001). Personality and performance at the beginning of the new millennium: What do we know and where do we go next? International Journal of Selection and Assessment, 9(June), 9-30. http://doi.org/10.1111/1468-2389.00160

Behrenbruch, K., Söllner, M., Leimeister, J. M., \& Schmidt, L. (2013). Understanding Diversity - The Impact of Personality on Technology Acceptance. Human-Computer Interaction, 8120(4), 306313.

Billón, M., Ezcurra, R., \& Lera-López, F. (2008). The spatial distribution of the internet in the European Union: Does geographical proximity matter? European Planning Studies, 16(1), 119-142. http://doi.org/10.1080/09654310701748009

Brandtzæg, P. B., Heim, J., \& Karahasanović, A. (2011). Understanding the new digital divide-A typology of Internet users in Europe. International Journal of Human-Computer Studies, 69(3), 123-138. http://doi.org/10.1016/j.ijhcs.2010.11.004

Butt, S., \& Phillips, J. G. (2008). Personality and self reported mobile phone use. Computers in Human Behavior, 24(2), 346-360. http://doi.org/10.1016/j.chb.2007.01.019

Childers, T. L., Carr, C. L., Joann, P., \& Carson, S. (2001). Hedonic and utilitarian motivation for online retail shopping behavior. Journal of Retailing, 77, 511-535. http://doi.org/10.1016/j.jretai.2006.1

Chin, W. W. (1998). Issues and opinion on structural equation modelling. MIS Quarterly, 22(1), 7-25.

Chong, A. Y.-L., Chan, F. T. S., \& Ooi, K.-B. (2012). Predicting consumer decisions to adopt mobile commerce: Cross country empirical examination between China and Malaysia. Decision Support Systems, 53(1), 34-43. http://doi.org/10.1016/j.dss.2011.12.001

Churchil, G. A. (1979). A Paradigm for Developing Better Measures of Marketing Constructs. Journal of Marketing Research, 16(2), 64-73. http://doi.org/10.1017/CBO9781107415324.004

Çilan, Ç., a, Bolat, B. A., \& Coşkun, E. (2009). Analyzing digital divide within and between member and candidate countries of European Union. Government Information Quarterly, 26(1), 98-105. http://doi.org/10.1016/j.giq.2007.11.002

Compeau, D. R., \& Higgins, C. A. . (1995). Development of a Measure and Initial Test. MIS Quarterly, 19(2), 189-211.

Cooper, A. J., Smillie, L. D., \& Corr, P. J. (2010). A confirmatory factor analysis of the Mini-IPIP fivefactor model personality scale. Personality and Individual Differences, 48(5), 688-691. http://doi.org/10.1016/j.paid.2010.01.004

Correa, T. (2010). Who interacts on the Web?: The intersection of users' personality and social media use. Computers in Human Behavior, 26(2), 247-253. http://doi.org/10.1016/j.chb.2009.09.003

Costa, \& McCrae, R. R. (1992). Neo PI-R professional manual. Psychological Assessment Resources, 4(1), 5-13. http://doi.org/10.1037/0003-066X.52.5.509

Costa, P. T. J., \& McCrae, R. R. (1992). Normal Personality Assessment in Clinical Practice: The NEO Personality Inventory. Psychological Assessment, 4(1), 5-13. http://doi.org/10.1037//1040- 
3590.4.1.5

Cruz-Jesus, F., Oliveira, T., \& Bacao, F. (2012). Digital divide across the European Union. Information \& Management, 49(6), 278-291. http://doi.org/10.1016/j.im.2012.09.003

Cruz-Jesus, F., Vicente, M. R., Bacao, F., \& Oliveira, T. (2016). The education-related digital divide: An analysis for the EU-28. Computers in Human Behavior, 56, 72-82. http://doi.org/10.1016/j.chb.2015.11.027

Davis, F. D. (1989). Perceived Ease of Use, and User Acceptance of Information Technology. MIS Quarterly, 13(3), 319-340. http://doi.org/10.2307/249008

Davis, F. D., Bagozzi, R. P., \& Warshaw, P. R. (1992). Extrinsic and Intrinsic Motivation to Use Computers in the Workplace1. Journal of Applied Social Psychology, 22(14), 1111-1132. http://doi.org/10.1111/j.1559-1816.1992.tb00945.x

Devaraj, S., Easley, R., \& Grant, J. M. (2008). How Does Personality Matter? Relating the Five-Factor Model to Technology Acceptance and Use. Information Systems Research, 19, 93-105.

Dewan, S., \& Riggins, F. J. (2005). The Digital Divide: Current and Future Research Directions. Journal of the Association for Information Systems, 6(12), 298-337.

Digman, J. M. (1990). Personality Structure : Emergence of the Five-Factor Model. Annual Review of Psychology, 41, 414-440.

DiMaggio, P., Hargittai, E., Celeste, C., \& Shafer, S. (2004). From unequal access to differentiated use: A literature review and agenda for research on digital inequality. Neckerman, K.M. (Ed.).Social Inequality. Russell Sage Foundation, New York, 355-400.

Dodds, W. B., Monroe, K. B., \& Grewal, D. (1991). Effects of Price, Brand, and Store Information on Buyers' Product Evaluations. Journal of Marketing Research, 28(3), 307-319. http://doi.org/10.2307/3172866

Donnellan, M. B., Oswald, F. L., Baird, B. M., \& Lucas, R. E. (2006). The mini-IPIP scales: tiny-yeteffective measures of the Big Five factors of personality. Psychological Assessment, 18(2), 192 203. http://doi.org/10.1037/1040-3590.18.2.192

Epstein, D., Newhart, M., \& Vernon, R. (2014). Not by technology alone: The "analog" aspects of online public engagement in policymaking. Government Information Quarterly, 31(2), 337-344. http://doi.org/10.1016/j.giq.2014.01.001

European Commission. (2010). A Digital Agenda for Europe. Communication, 5(245 final/2), 42. http://doi.org/COM(2010)245

European Commission. (2012). Unleashing the Potential of Cloud Computing in Europe. COMMUNICATION FROM THE COMMISSION TO THE EUROPEAN PARLIAMENT, THE COUNCIL, THE EUROPEAN ECONOMIC AND SOCIAL COMMITTEE AND THE COMMITTEE OF THE REGIONS.

European Commission. (2013). Unlocking the ICT growth potential in Europe : Enabling people and businesses. Digital Agenda Europe. http://doi.org/10.2759/38215

European Commission. (2015). A Digital Single Market Strategy for Europe. Brussels.

Eurostat. (2013). Science, technology and innovation in Europe 2013. http://doi.org/10.2785/35613

Fishbein, M., \& Ajzen, I. (1975). Belief, Attitude, Intention, and Behavior: An Introduction to Theory and Research. Reading, MA: Addison-Wesley. http://doi.org/10.1017/CBO9781107415324.004

Fornell, C., \& Larcker, D. F. (1981). Structural Equation Models with Unobservable Variables and Measurement Error: Algebra and Statistics. Journal of Marketing Research, 18(3), 382-388. http://doi.org/10.2307/3150980

Fraj, E., \& Martinez, E. (2006). Influence of personality on ecological consumer behaviour. Journal of Consumer Behaviour, 12(4), 167-181. http://doi.org/10.1002/cb

Gosling, S. D., Rentfrow, P. J., \& Swann, W. B. (2003). A very brief measure of the Big-Five personality domains. Journal of Research in Personality, 37(6), 504-528. http://doi.org/10.1016/S0092-6566(03)00046-1 
Gulati, G. J. “Jeff," Williams, C. B., \& Yates, D. J. (2014). Predictors of on-line services and eparticipation: A cross-national comparison. Government Information Quarterly, 31(4), 526-533. http://doi.org/10.1016/j.giq.2014.07.005

Haight, M., Quan-Haase, A., \& Corbett, B. A. (2014). Revisiting the digital divide in Canada: the impact of demographic factors on access to the internet, level of online activity, and social networking site usage. Information, Communication \& Society, 17(4), 503-519. http://doi.org/10.1080/1369118X.2014.891633

Hair, J. F., \& Anderson, R. E. (2010). Multivariate Data Analysis. Prentice Hall.

Hargittaia, E., \& Hsiehb, Y. P. (2010). Predictors and Consequences of Differenciated Practices on Social Network Sites. Information, Communication \& Society, 13(4), 515-536.

Heijden, H. Van Der. (2004). User acceptance of hedonic information systems^^. MIS Quarterly, 28(4), 695-704. http://doi.org/10.2307/25148660

Henseler, J., Ringleand, C. M., \& Sinkovics, R. R. (2009). The use of partial least squares path modelling in international marketing. New Challenges to International Marketing, 20, 277-319. http://doi.org/10.1016/0167-8116(92)90003-4

Hilbert, M. (2011). The end justifies the definition: The manifold outlooks on the digital divide and their practical usefulness for policy-making. Telecommunications Policy, 35(8), 715-736. http://doi.org/10.1016/j.telpol.2011.06.012

Hofstede, G. (2016). The Hofstede Center. Retrieved November 20, 2016, from https://geerthofstede.com/bulgaria.html

Hughes, D. J., Rowe, M., Batey, M., \& Lee, A. (2012). A tale of two sites: Twitter vs. Facebook and the personality predictors of social media usage. Computers in Human Behavior, 28(2), 561-569. http://doi.org/10.1016/j.chb.2011.11.001

Hung, S.-Y., Chang, C.-M., \& Kuo, S.-R. (2013). User acceptance of mobile e-government services: An empirical study. Government Information Quarterly, 30(1), 33-44. http://doi.org/10.1016/j.giq.2012.07.008

Hunsinger, M., Poirier, C. R., \& Feldman, R. S. (2008). The roles of personality and class size in student attitudes toward individual response technology. Computers in Human Behavior, 24(6), 2792-2798. http://doi.org/10.1016/j.chb.2008.04.003

ITU. (2014). Measuring the Information Society Report 2014.

ITU. (2015). ICT Facts \& Figures. The world in 2015. Retrieved from http://www.itu.int/en/ITUD/Statistics/Documents/facts/ICTFactsFigures2015.pdf

ITU. (2016). ICT Facts and figures 2016, 8. http://doi.org/10.1787/9789264202085-5-en

Judge, T. A., Higgins, C. A., Thoresen, C. J., \& Barrick, M. R. (1999). The big five personality traits, general mental ability, and career success across the life span. Personnel Psychology, 52, 621.

Kleine, J., Wagner, N., \& Weller, T. (2015). Openness Endangers your Wealth: Noise Trading and the Big Five. Finance Research Letters. http://doi.org/10.1016/j.frl.2015.12.002

Kokkinos, C. M., Baltzidis, E., \& Xynogala, D. (2016). Prevalence and personality correlates of Facebook bullying among university undergraduates. Computers in Human Behavior, 55, 840 850. http://doi.org/10.1016/j.chb.2015.10.017

Korukonda, A. R. (2007). Differences that do matter: A dialectic analysis of individual characteristics and personality dimensions contributing to computer anxiety. Computers in Human Behavior, 23(4), 1921-1942. http://doi.org/10.1016/j.chb.2006.02.003

Kvasova, O. (2015). The Big Five personality traits as antecedents of eco-friendly tourist behavior. Personality and Individual Differences, 83, 111-116. http://doi.org/10.1016/j.paid.2015.04.011

Landers, R. N., \& Lounsbury, J. W. (2006). An investigation of Big Five and narrow personality traits in relation to Internet usage. Computers in Human Behavior, 22(2), 283-293. http://doi.org/10.1016/j.chb.2004.06.001

Lee, H., Park, N., \& Hwang, Y. (2015). A new dimension of the digital divide: Exploring the relationship between broadband connection, smartphone use and communication competence. Telematics 
and Informatics, 32(1), 45-56. http://doi.org/10.1016/j.tele.2014.02.001

Li, Y., Tan, C. H., Teo, H. H., \& Tan, B. C. Y. (2006). Innovative usage of information technology in Singapore Organizations: Do ClO characteristics make a difference? In IEEE Transactions on Engineering Management (Vol. 53, pp. 177-190). http://doi.org/10.1109/TEM.2006.872250

Lian, J.-W., \& Yen, D. C. (2014). Online shopping drivers and barriers for older adults: Age and gender differences. Computers in Human Behavior, 37, 133-143. http://doi.org/10.1016/j.chb.2014.04.028

Limayem, M., Hirt, S. G., \& Cheung, C. M. K. (2007). How Habit Limits the Predictive Power of Intention: the Case of Information Systems Continuance 1. MIS Quarterly, 31(4), 705-737.

Magsamen-Conrad, K., Upadhyaya, S., Joa, C. Y., \& Dowd, J. (2015). Bridging the Divide: Using UTAUT to predict multigenerational tablet adoption practices. Computers in Human Behavior, 50, 186-196. http://doi.org/10.1016/j.chb.2015.03.032

McCrae, R. R., \& John, O. P. (1992). An Introduction to the Five-Factor Model and Its Applications. Journal of Personality, 60(2), 175-215. http://doi.org/10.1111/j.1467-6494.1992.tb00970.x

McElroy, J., Hendrickson, A., \& Townsend, A. (2007). Dispositional Factors in Internet Use: Personality versus Cognitive Style. MIS Quarterly, 31(4), 809-820.

Mendonça, S., Crespo, N., \& Simões, N. (2015). Inequality in the network society: An integrated approach to ICT access, basic skills, and complex capabilities. Telecommunications Policy, 39(34), 192-207. http://doi.org/10.1016/j.telpol.2014.12.010

Morosan, C., \& DeFranco, A. (2016). It's about time: Revisiting UTAUT2 to examine consumers' intentions to use NFC mobile payments in hotels. International Journal of Hospitality Management, 53, 17-29. http://doi.org/10.1016/j.ijhm.2015.11.003

Niehaves, B., \& Plattfaut, R. (2013). Internet adoption by the elderly: employing IS technology acceptance theories for understanding the age-related digital divide. European Journal of Information System, (January 2012), 1-19. http://doi.org/10.1057/ejis.2013.19

Noë, N., Whitaker, R. M., Chorley, M. J., \& Pollet, T. V. (2016). Birds of a feather locate together? Foursquare checkins and personality homophily. Computers in Human Behavior, 58, 343-353. http://doi.org/10.1016/j.chb.2016.01.009

OECD. (2001). Understanding the Digital Divide.

Ouellette, J. A., \& Wood, W. (1998). Habit and Intention in Everyday Life: The Multiple Processes by Which Past Behavior Predicts Future Behavior. Psychological Bulletin, 124(1), 124-54. http://doi.org/10.1037/0033-2909.124.1.54

Picazo-Vela, S., Chou, S. Y., Melcher, A. J., \& Pearson, J. M. (2010). Why provide an online review? An extended theory of planned behavior and the role of Big-Five personality traits. Computers in Human Behavior, 26(4), 685-696. http://doi.org/10.1016/j.chb.2010.01.005

Ringle, C., Wende, S., \& Becker, J. (2015). SmartPLS 3. Bönningstedt: SmartPLS. Retrieved from.

Rogers, E. M. (1995). Diffusion of innovations. Macmillian Publishing Co. http://doi.org/citeulike-articleid: 126680

Sato, A., \& Costa-i-Font, J. (2013). Social networking for medical information: A digital divide or a trust inquiry? Health Policy and Technology, 2(3), 139-150. http://doi.org/10.1016/j.hlpt.2013.05.002

Shim, H., You, K. H., Lee, J. K., \& Go, E. (2015). Why do people access news with mobile devices? Exploring the role of suitability perception and motives on mobile news use. Telematics and Informatics, 32(1), 108-117. http://doi.org/10.1016/j.tele.2014.05.002

Straub, D., Limayem, M., \& Karahanna-Evaristo, E. (1995). Measuring System Usage: Implications for IS Theory Testing. Management Science, 41(8), 1328-1342. http://doi.org/10.1287/mnsc.41.8.1328

Svendsen, G. B., Johnsen, J.-A. K., Almås-Sørensen, L., \& Vittersø, J. (2011). Personality and technology acceptance: the influence of personality factors on the core constructs of the Technology Acceptance Model. Behaviour \& Information Technology, 32(4), 323-334. http://doi.org/10.1080/0144929X.2011.553740 
Tang, J.-H., Chen, M.-C., Yang, C.-Y., Chung, T.-Y., \& Lee, Y.-A. (2016). Personality traits, interpersonal relationships, online social support, and Facebook addiction. Telematics and Informatics, 33(1), 102-108. http://doi.org/10.1016/j.tele.2015.06.003

Taylor, S., \& Todd, P. (1995). Assessing IT usage: The role of prior experience. Management Information Systems Quarterly, 19(4), 561-570. http://doi.org/10.2307/249633

Terzis, V., Moridis, C. N., \& Economides, A. A. (2012). How student's personality traits affect Computer Based Assessment Acceptance: Integrating BFI with CBAAM. Computers in Human Behavior, 28(5), 1985-1996. http://doi.org/10.1016/j.chb.2012.05.019

Thompson, R. L., Higgins, C. a., \& Howell, J. . (1991). Personal Computing : Toward a Conceptual Model of Utilization. MIS Quarterly, 15(1), 124-143. http://doi.org/10.2307/249443

US Department of Commerce. (1995). Falling Through the Net: A Survey of the "Have Nots" in Rural and Urban America, National Telecommunications and Information Administration.

US Department of Commerce. (1998). Falling through the Net II: New Data on the Digital Divide, National Telecommunications and Information Administraion.

US Department of Commerce. (1999). Falling through the Net: Defining the Digital Divide, National Telecommunications and Information Administration.

US Department of Commerce. (2000). Falling Through the Net: Toward Digital Inclusion, National Telecommunications and Information Administration.

van Dijk, J. A. G. M. (2006). Digital divide research, achievements and shortcomings. Poetics, 34(4-5), 221-235. http://doi.org/10.1016/j.poetic.2006.05.004

Venkatesh, V., Morris, M. G., Davis, G. B., \& Davi, F. D. (2003). User acceptance of information technology: Toward a unified view. MIS Quarterly, 27(3), 425-478. http://doi.org/10.2307/30036540

Venkatesh, V., Thong, J. Y. L., \& Xu, X. (2012). Consumer Acceptance and Use of Information Technology: Extending the Unified Theory. MIS Quarterly, 36(1), 157-178.

Vicente Cuervo, M. R., \& López Menéndez, A. J. (2006). A multivariate framework for the analysis of the digital divide: Evidence for the European Union-15. Information \& Management, 43(6), 756766. http://doi.org/10.1016/j.im.2006.05.001

Vicente, M. R., \& López, A. J. (2006). Patterns of ICT diffusion across the European Union. Economics Letters, 93(1), 45-51. http://doi.org/10.1016/j.econlet.2006.03.039

Vicente, M. R., \& López, A. J. (2008). Some empirical evidence on Internet diffusion in the New Member States and Candidate Countries of the European Union. Applied Economics Letters, 15(13), 1015-1018. http://doi.org/10.1080/13504850600972352

Vicente, M. R., \& López, A. J. (2011). Assessing the regional digital divide across the European Union-27. Telecommunications Policy, 35(3), 220-237. http://doi.org/10.1016/j.telpol.2010.12.013

Vicente, M. R., \& Novo, A. (2014). An empirical analysis of e-participation. The role of social networks and e-government over citizens' online engagement. Government Information Quarterly, 31(3), 379-387. http://doi.org/10.1016/j.giq.2013.12.006

Walczuch, R., \& Lundgren, H. (2004). Psychological antecedents of institution-based consumer trust in e-retailing. Information and Management, 42(1), 159-177. http://doi.org/10.1016/j.im.2003.12.009

Wattal, S., Schuff, D., \& Mandviwalla, M. (2010). Web 2.0 and Politics: The 2008 U.S. Presidential Election and an E-Politics Research Agenda. MIS Quarterly, 34(4), 669-688.

Workman, M. (2014). New media and the changing face of information technology use: The importance of task pursuit, social influence, and experience. Computers in Human Behavior, 31, 111-117. http://doi.org/10.1016/j.chb.2013.10.008

World Bank. (2014). The Little Data Book on Information and Communication Technology 2014.

Xu, R., Frey, R. M., Fleisch, E., \& llic, A. (2016). Understanding the impact of personality traits on mobile app adoption - Insights from a large-scale field study. Computers in Human Behavior, 62, 
244-256. http://doi.org/10.1016/j.chb.2016.04.011

Zhang, X. (2013). Income disparity and digital divide: The Internet Consumption Model and crosscountry empirical research. Telecommunications Policy, 37(6-7), 515-529.

http://doi.org/10.1016/j.telpol.2012.12.011

Zhou, T., \& Lu, Y. (2011). The Effects of Personality Traits on User Acceptance of Mobile Commerce. International Journal of Human-Computer Interaction, 27(6), 545-561.

http://doi.org/10.1080/10447318.2011.555298 


\section{APPENDIX}

\subsection{APPENDIX A - INSTRUMENT}

\begin{tabular}{|c|c|c|c|}
\hline Construct & Item & Code & Source \\
\hline \multirow{4}{*}{$\begin{array}{c}\text { Performance } \\
\text { expectancy (PE) }\end{array}$} & I find ICT useful in my daily life & PE1 & \multirow{4}{*}{$\begin{array}{l}\text { Venkatesh et } \\
\text { al. }(2003 ; 2012)\end{array}$} \\
\hline & Using ICT increases my productivity & PE2 & \\
\hline & Using ICT helps me accomplish things more quickly & PE3 & \\
\hline & Using ICT increases my chances of achieving things that are important to me & PE4 & \\
\hline \multirow{4}{*}{$\begin{array}{l}\text { Effort expectancy } \\
\text { (EE) }\end{array}$} & Learning how to use ICT is easy for me & EE1 & \multirow{4}{*}{$\begin{array}{l}\text { Venkatesh et } \\
\text { al. }(2003 ; 2012)\end{array}$} \\
\hline & My interaction with ICT is clear and understandable & EE2 & \\
\hline & I find ICT easy to use & EE3 & \\
\hline & It is easy for me to become skillful at using ICT & EE4 & \\
\hline \multirow{4}{*}{$\begin{array}{l}\text { Social influence } \\
\text { (SI) }\end{array}$} & People who are important to me think that I should use ICT & SI1 & \multirow{4}{*}{$\begin{array}{l}\text { Venkatesh et } \\
\text { al. }(2003 ; 2012)\end{array}$} \\
\hline & People who influence my behavior think that I should use ICT & SI2 & \\
\hline & ICT use is a status symbol in my environment & $\mathrm{SI} 3$ & \\
\hline & People whose opinions I value prefer that I use ICT & $\mathrm{SI} 4$ & \\
\hline \multirow{4}{*}{$\begin{array}{c}\text { Facilitating } \\
\text { conditions (FC) }\end{array}$} & I have the resources necessary to use ICT & FC1 & \multirow{4}{*}{$\begin{array}{l}\text { Venkatesh et } \\
\text { al.(2003;2012) }\end{array}$} \\
\hline & I have the knowledge necessary to use ICT & FC2 & \\
\hline & There is compatibility between the ICT I use & FC3 & \\
\hline & I can get help from others when I have difficulties using ICT & FC4 & \\
\hline \multirow{3}{*}{$\begin{array}{c}\text { Hedonic } \\
\text { motivation (HM) }\end{array}$} & Using ICT is fun & HM1 & \multirow{3}{*}{$\begin{array}{l}\text { (Venkatesh et } \\
\text { al., 2012) }\end{array}$} \\
\hline & Using ICT is enjoyable & HM2 & \\
\hline & Using ICT is entertaining & HM3 & \\
\hline \multirow{3}{*}{ Price value $(\mathrm{PV})$} & ICTs are reasonably priced & PV1 & \multirow{3}{*}{$\begin{array}{l}\text { (Venkatesh et } \\
\text { al., 2012) }\end{array}$} \\
\hline & ICT are a good value for the money & PV2 & \\
\hline & At the current price, ICT provide a good value & PV3 & \\
\hline \multirow{4}{*}{ Habit (HB) } & The use of ICT has become a habit for me & HB1 & \multirow{4}{*}{$\begin{array}{l}\text { (Venkatesh et } \\
\text { al., 2012) }\end{array}$} \\
\hline & I am addicted to using ICT & HB2 & \\
\hline & I must use ICT & HB3 & \\
\hline & Using ICT has become natural to me & HB4 & \\
\hline \multirow{3}{*}{$\begin{array}{l}\text { Behavioral } \\
\text { intention (BI) }\end{array}$} & I intend to continue using ICT in the future & $\mathrm{Bl} 1$ & \multirow{3}{*}{$\begin{array}{l}\text { Venkatesh et } \\
\text { al.(2003;2012) }\end{array}$} \\
\hline & I will always try to use ICT in my daily life & $\mathrm{Bl} 2$ & \\
\hline & I plan to continue to use ICT frequently & $\mathrm{BI3}$ & \\
\hline $\begin{array}{l}\text { Usage behavior } \\
\text { (UB) }\end{array}$ & $\begin{array}{l}\text { Please choose your usage frequency for each of the following ICTs, where } \\
\text { frequency ranges from "1-never" to "7-many times per day": } \\
\text { a) Internet } \\
\text { b) access the Internet via a mobile device, away from home or work } \\
\text { c) use online banking } \\
\text { d) seek health-related information online } \\
\text { e) look for information about education, training or course offers online } \\
\text { f) interact with public authorities online } \\
\text { g) look for information about goods and services online } \\
\text { h) order goods or services online } \\
\text { i) order goods or services online, from sellers from other EU countries } \\
\text { j) online public participation (consultations or voting to define civic or } \\
\text { political issues) } \\
\text { k) social networks } \\
\text { l) storage space on the Internet (e.g., Google Drive, Dropbox) }\end{array}$ & UB & $\begin{array}{l}\text { (Venkatesh et } \\
\text { al., 2012) }\end{array}$ \\
\hline \multirow{4}{*}{ Openness (OPE) } & I have a vivid imagination & OPE1 & \multirow{4}{*}{$\begin{array}{l}\text { (Donnellan et } \\
\text { al., 2006) }\end{array}$} \\
\hline & I am not interested in abstract ideas (R) & OPE2 & \\
\hline & I have difficulty understanding abstract ideas $(\mathrm{R})$ & OPE3 & \\
\hline & I do not have a good imagination $(R)$ & OPE4 & \\
\hline \multirow{4}{*}{$\begin{array}{l}\text { Extraversion } \\
\quad(E X S)\end{array}$} & I am the life of the party & EXS1 & \multirow{4}{*}{$\begin{array}{l}\text { (Donnellan et } \\
\text { al., 2006) }\end{array}$} \\
\hline & I don't talk a lot $(\mathrm{R})$ & EXS2 & \\
\hline & I talk to a lot of different people at parties & EXS3 & \\
\hline & I keep in the backgrou & EXS4 & \\
\hline \multirow{4}{*}{$\begin{array}{l}\text { Agreeableness } \\
\text { (AGR) }\end{array}$} & I sympathize with others' feelings & AGR1 & \multirow{4}{*}{$\begin{array}{l}\text { (Donnellan et } \\
\text { al., 2006) }\end{array}$} \\
\hline & I am not interested in other people's problems (R) & AGR2 & \\
\hline & I feel others' emotions & AGR3 & \\
\hline & I am not really interested in others $(\mathrm{R})$ & AGR4 & \\
\hline & I get chores done right away & CON1 & \\
\hline & I often forget to put things back in their proper place $(\mathrm{R})$ & CON2 & (Donnellan et \\
\hline$(\mathrm{CON})$ & I like order & CON3 & al., 2006) \\
\hline & I make a mess of things $(\mathrm{R})$ & CON4 & \\
\hline & I have frequent mood swings & NEU1 & \\
\hline Nournticism (NFI) & I am relaxed most of the time $(\mathrm{R})$ & NEU2 & (Donnellan et \\
\hline Neuroticism (NEU) & I get upset easily & NEU3 & al., 2006) \\
\hline & I seldom feel blue $(\mathrm{R})$ & NEU4 & \\
\hline
\end{tabular}




\subsection{APPENDIX B - LOADINGS AND CROSS-LOADINGS}

\begin{tabular}{|c|c|c|c|c|c|c|c|c|c|c|c|c|c|}
\hline & 'E & EE & SI & FC & HM & PV & HB & BI & OPE & EXS & AGR & CON & NEU \\
\hline PE1 & 927 & 595 & 347 & 0.684 & 0.629 & 0.388 & .560 & 0.751 & 0.367 & -0.076 & 0.276 & 0.198 & -0.232 \\
\hline PE2 & 948 & 627 & 361 & 0.662 & 0.559 & 392 & .531 & 0.712 & .427 & -0.050 & 0.244 & 0.143 & 0.272 \\
\hline PE3 & 950 & 0.608 & 0.377 & 0.657 & 0.571 & 0.371 & .514 & 0.693 & 0.402 & -0.053 & 0.213 & 0.198 & 0.256 \\
\hline PE4 & 939 & 0.611 & 0.406 & 0.631 & 0.565 & 0.381 & 0.556 & 0.717 & 0.407 & -0.045 & 0.226 & 0.108 & 0.283 \\
\hline EE1 & 575 & 0.944 & 0.341 & 0.626 & 0.580 & 0.450 & 0.516 & 0.522 & 0.400 & -0.050 & 0.214 & 0.052 & .353 \\
\hline EE2 & 642 & 0.948 & 0.371 & 0.677 & 0.615 & 0.462 & 0.539 & 0.557 & 0.435 & -0.047 & 0.269 & 0.087 & 0.306 \\
\hline EE3 & 303 & 954 & 368 & 0.650 & .598 & 0.464 & 523 & 0.552 & 480 & -0.004 & 0.265 & .079 & 354 \\
\hline EE4 & 625 & 0.928 & 0.330 & 0.689 & 0.554 & 0.415 & 15 & 0.573 & 460 & -0.059 & 0.239 & .089 & .301 \\
\hline SI1 & 30 & 0.356 & 83 & 0.406 & 0.365 & 0.406 & 14 & 438 & 228 & 58 & 268 & 060 & 279 \\
\hline SI2 & 382 & 0.335 & 399 & 0.402 & 339 & 0.395 & 38 & 33 & 231 & 62 & 38 & 68 & 172 \\
\hline $\mathrm{SI3}$ & 244 & 0.297 & 0.742 & 0.216 & 0.203 & 0.174 & 445 & 0.346 & 0.215 & -0.067 & 0.265 & 105 & -0.201 \\
\hline $\mathrm{SI} 4$ & 326 & 0.301 & 0.908 & 0.330 & 0.321 & 0.357 & 443 & 458 & 240 & -0.071 & 0.261 & 076 & 306 \\
\hline FC1 & 589 & 0.627 & 0.356 & 0.879 & 0.478 & 0.453 & 493 & 0.542 & 0.333 & 22 & 0.208 & 573 & 272 \\
\hline FC2 & 651 & 0.682 & 0.365 & \begin{tabular}{|l|}
0.893 \\
\end{tabular} & 0.506 & 0.346 & 0.527 & .564 & .411 & -0.047 & \begin{tabular}{|l|}
0.259 \\
\end{tabular} & 991 & 0.240 \\
\hline FC3 & 639 & 0.607 & 0.326 & 0.884 & 0.560 & 0.436 & 0.483 & 0.532 & 0.389 & -0.014 & 0.251 & 0.129 & -0.205 \\
\hline FC4 & 0.578 & 0.538 & 0.353 & 0.856 & 0.535 & 0.487 & 0.481 & 0.560 & 0.383 & -0.027 & 0.245 & 0.118 & -0.230 \\
\hline HM1 & 0.514 & 0.619 & 0.334 & 0.555 & 0.934 & 0.494 & 0.497 & 0.522 & 0.271 & 0.029 & 0.226 & 0.118 & -0.203 \\
\hline HM2 & 0.619 & 0.605 & 0.332 & 0.569 & 0.948 & 0.480 & 0.487 & 0.622 & 0.261 & -0.011 & 0.226 & 0.185 & -0.203 \\
\hline HM3 & 599 & 0.526 & 352 & 0.538 & 0.932 & 0.482 & 0.473 & 0.555 & 0.255 & -0.041 & 0.206 & 0.222 & -0.176 \\
\hline$P$ & 319 & 0.438 & 386 & 0.411 & 466 & 34 & 0.372 & 0.320 & 0.242 & 0.014 & 0.181 & 0.041 & 0.277 \\
\hline PV2 & 87 & 436 & 345 & 0.451 & 504 & 0.951 & 356 & 0.376 & 0.242 & -0.007 & 0.178 & 081 & .229 \\
\hline PV3 & & 0.465 & 9 & 7 & 9 & 0.941 & 03 & 32 & 73 & - & 07 & 13 & 250 \\
\hline HB1 & & 0.564 & 397 & 0.621 & & & & 3 & & & 6 & & 01 \\
\hline HB2 & & & & & & & & & & & & 44 & 21 \\
\hline HB3 & + & 0.311 & 8 & 5 & 0.291 & 3 & 3 & 33 & 2 & 15 & 71 & 27 & 275 \\
\hline HB4 & 580 & 0.581 & 0.404 & 0.561 & 0.536 & 0.345 & 908 & 0.659 & 0.332 & -0.017 & 0.231 & 073 & -0.312 \\
\hline $\mathrm{BI}(\mathrm{I}) 1$ & 765 & \begin{tabular}{|l}
0.575 \\
\end{tabular} & 0.446 & \begin{tabular}{|l}
0.650 \\
\end{tabular} & 0.614 & 0.414 & 0.605 & 0.912 & 0.412 & -0.044 & \begin{tabular}{|l|}
0.343 \\
\end{tabular} & \begin{tabular}{|l|}
0.181 \\
\end{tabular} & \begin{tabular}{|l}
-0.263 \\
\end{tabular} \\
\hline $\mathrm{BI}(\mathrm{I}) 2$ & 0.628 & 0.468 & 0.428 & 0.497 & 0.472 & 0.332 & 0.566 & 0.899 & 0.366 & -0.027 & 0.215 & 0.051 & \begin{tabular}{|l|}
-0.306 \\
\end{tabular} \\
\hline $\mathrm{BI}(\mathrm{I}) 3$ & 0.716 & 0.569 & 0.480 & 0.578 & 0.586 & 0.315 & 0.645 & 0.957 & 0.405 & -0.054 & 0.289 & 0.108 & -0.317 \\
\hline OPE1 & 0.453 & 0.461 & 0.287 & 0.433 & 0.301 & 0.269 & 0.382 & 0.451 & 0.874 & 0.190 & 0.360 & -0.018 & -0.311 \\
\hline OPE2R & 0.291 & 0.372 & 0.176 & 0.329 & 0.209 & 0.208 & 0.223 & 0.279 & 0.809 & 0.045 & 0.254 & -0.107 & -0.210 \\
\hline OPE3R & 0.270 & 0.370 & 0.195 & 0.346 & 0.179 & 0.186 & 0.202 & 0.293 & 0.833 & 0.112 & 0.271 & -0.065 & -0.266 \\
\hline OPE4R & 386 & 380 & 0.217 & 0.340 & 0.233 & 0.232 & 0.310 & 0.387 & 0.875 & 0.075 & 0.360 & -0.021 & -0.241 \\
\hline EXS1 & .044 & .019 & .046 & -0.032 & .008 & .028 & 0.030 & -0.026 & 147 & 0.952 & \begin{tabular}{|l|}
-0.229 \\
\end{tabular} & -0.110 & -0.121 \\
\hline EXS2R & .039 & 122 & -0.149 & .035 & 013 & -0.026 & 63 & 59 & 89 & 31 & -0.208 & 035 & .075 \\
\hline EXS3 & .065 & -0.052 & -0.096 & .026 & 08 & 20 & -0.001 & -0.053 & 0.086 & 0.915 & -0.190 & -0.066 & -0.075 \\
\hline EXS4R & .002 & -0.147 & -0.214 & -0.044 & -0.014 & -0.071 & -0.103 & -0.031 & .052 & 0.669 & -0.259 & 058 & 075 \\
\hline AGR1 & 0.255 & 0.279 & 0.306 & 0.322 & 0.265 & 0.207 & 0.255 & 0.296 & 0.320 & -0.207 & 0.919 & 0.085 & 0.099 \\
\hline AGR2R & .225 & 0.212 & 0.249 & 0.194 & 0.168 & 0.167 & 0.200 & 0.280 & 0.356 & -0.202 & 0.910 & 0.079 & -0.023 \\
\hline AGR3 & 0.183 & 0.226 & 0.374 & 0.224 & 0.187 & 0.218 & 208 & 0.227 & 0.340 & -0.199 & 0.873 & .051 & -0.105 \\
\hline AGR4R & .251 & 0.225 & 0.264 & 0.242 & 0.217 & 0.137 & 0.195 & 0.303 & 0.340 & -0.206 & 0.906 & .131 & -0.009 \\
\hline CON1 & 145 & 0.055 & -0.107 & 0.085 & 0.074 & 61 & 46 & 75 & 22 & 77 & 10 & 92 & .021 \\
\hline CON3 & 0.173 & 0.105 & -0.026 & 0.150 & 0.235 & 0.131 & 99 & 30 & -0.069 & 94 & 72 & 888 & -0.043 \\
\hline CON4R & 0.094 & 0.027 & -0.102 & 0.031 & 0.130 & -0.007 & -0.019 & 0.097 & -0.087 & -0.160 & 0.060 & 0.775 & -0.034 \\
\hline NEU2R & -0.224 & -0.331 & -0.251 & -0.279 & -0.208 & -0.306 & -0.257 & -0.274 & -0.248 & -0.067 & -0.086 & -0.048 & 0.886 \\
\hline NEU4R & -0.274 & -0.304 & -0.258 & -0.218 & -0.172 & -0.190 & -0.299 & -0.303 & -0.305 & -0.095 & -0.036 & -0.028 & 0.927 \\
\hline
\end{tabular}

